\title{
Expression-based and co-localization detection of arabinogalactan protein 6 and arabinogalactan protein 11 interactors in Arabidopsis pollen and pollen tubes
}

Mário Costa ${ }^{1,2}$, Margarida Sofia Nobre ${ }^{1,2}$, Jörg D Becker ${ }^{3}$, Simona Masiero ${ }^{4}$, Maria Isabel Amorim, Luís Gustavo Pereira ${ }^{1,2}$ and Sílvia Coimbra ${ }^{1,2^{*}}$

\begin{abstract}
Background: Arabinogalactan proteins (AGPs) are cell wall proteoglycans that have been shown to be important for pollen development. An Arabidopsis double null mutant for two pollen-specific AGPs (agp6 agp 11) showed reduced pollen tube growth and compromised response to germination cues in vivo. A microarray experiment was performed on agp6 agp 11 pollen tubes to search for genetic interactions in the context of pollen tube growth. A yeast two-hybrid experiment for AGP6 and AGP11 was also designed.

Results: The lack of two specific AGPs induced a meaningful shift in the gene expression profile. In fact, a high number of genes showed altered expression levels, strengthening the case that AGP6 and AGP11 are involved in complex phenomena. The expression levels of calcium- and signaling-related genes were found to be altered, supporting the known roles of the respective proteins in pollen tube growth. Although the precise nature of the proposed interactions needs further investigation, the putative involvement of AGPs in signaling cascades through calmodulin and protein degradation via ubiquitin was indicated. The expression of stress-, as well as signaling- related, genes was also changed; a correlation that may result from the recognized similarities between signaling pathways in both defense and pollen tube growth.

The results of yeast two-hybrid experiments lent further support to these signaling pathways and revealed putative AGP6 and AGP11 interactors implicated in recycling of cell membrane components via endocytosis, through clathrin-mediated endosomes and multivesicular bodies.

Conclusions: The data presented suggest the involvement of AGP6 and AGP11 in multiple signaling pathways, in particular those involved in developmental processes such as endocytosis-mediated plasma membrane remodeling during Arabidopsis pollen development. This highlights the importance of endosomal trafficking pathways which are rapidly emerging as fundamental regulators of the wall physiology.
\end{abstract}

Keywords: Arabidopsis, Arabinogalactan proteins, Pollen tube, Microarray, Yeast two-hybrid

\footnotetext{
*Correspondence: scoimbra@fc.up.pt

'Departamento de Biologia, Faculdade de Ciências, Universidade do Porto,

Edifício FC4 Rua do Campo Alegre, 4169-007, Porto, Portugal

${ }^{2}$ BioFIG, Center for Biodiversity, Functional and Integrative Genomics, Porto,

Portugal

Full list of author information is available at the end of the article
}

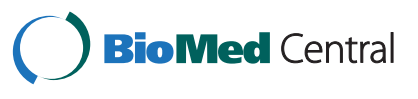

(c) 2013 Costa et al.; licensee BioMed Central Ltd. This is an Open Access article distributed under the terms of the Creative Commons Attribution License (http://creativecommons.org/licenses/by/2.0), which permits unrestricted use, distribution, and reproduction in any medium, provided the original work is properly cited. 


\section{Background}

Pollen-pistil interaction is initiated when the male gametophyte is transferred from the anther to the stigma. The pollen grain then starts to hydrate and germinate, forming a pollen tube that grows through the carpel's internal tissues to deliver its two sperm cells into the embryo sac. Pollen tubes elongate through the extracellular matrix of the pistil tissues, extending by an actin-myosin-based tipgrowth mechanism that transports vesicles loaded with new cell wall material to the extending apex and finally, when arriving at the embryo sac, enter into the synergid cell. Fundamentally during this type of localised, tipfocused growth, the cytoplasm is polarized directing secretory events to the tip. Internal gradients and transmembrane ion fluxes, notably of calcium ions, are another key feature of pollen tube growth [1].

Arabidopsis pollen transcriptome analysis showed the expression of a unique subset of genes relative to the sporophytic tissues [2-6]. Furthermore, changes in gene expression patterns occur during the development of the male gametophyte from a microspore to a mature tricellular pollen grain [7]. More recently, genome-wide expression profiling of pollen tubes grown in vitro identified another set of genes that are expressed in the pollen tube but not in pollen, which suggests de novo mRNA synthesis in the growing pollen tube [5]. The gene expression profiles of in vitro- and semi in vivo-grown Arabidopsis pollen tubes have also been characterized and were found to differ; this lead to the discovery of a specific sub-set of genes that are activated by potentiation of the pollen tube by the pistil [6].

Among the genes, or gene families that may be involved in the transition from a sporophytic to a gametophyticdevelopmental program are those which code for arabinogalactan proteins (AGP). AGPs constitute a large family of cell wall proteoglycans that are found on the plasma membrane, in the cell wall, in the apoplastic space, and in secretions. They have also been found in detergent-resistant membranes isolated from Arabidopsis suggesting their presence in lipid rafts [8]. Key distinguishing features of AGPs are: (1) the carbohydrate, usually branched type II arabino-3,6-galactan, O-linked to Hyp residues of the protein backbone, which constitutes $90-98 \%(\mathrm{w} / \mathrm{w})$ of the molecular mass, (2) the protein backbone typically rich in the dipeptide motifs Ala-Hyp, Ser-Hyp, Thr-Hyp, Val-Pro, Gly-Pro and Thr-Pro, (3) a glycosylphosphatidylinositol (GPI) membrane anchor, predicted to be present on most, but not all, AGPs and (4) the ability to bind to a class of synthetic chemical dyes, known as Yariv reagents [9], which are not only useful for detection, quantification and isolation of AGPs, but also for functional studies [10].

The identification of Arabidopsis pollen-specific AGP genes has been used to scrutinize phenotypic changes in the respective null mutants. We previously identified two male gametophyte AGP genes (AGP6 and AGP11) which showed functional redundancy [11]. An agp6 agp11 double null mutant was subsequently obtained. The double null mutant exhibited segregation distortion, as assessed by the number of aborted pollen grains, suggesting that the gametophyte generation was affected. The strong reduction in pollen germination and pollen tube growth rate, together with premature ectopic germination of pollen (whilst it was still in the anther) [12], prompted us to further analyze this mutant, in order to gain insight into the mode of action of AGPs. We decided to examine the transcriptome of the agp6 agp11 double null mutant pollen tubes, using the Affymetrix ATH1 Genome Array.

Here we report the identification of 1022 genes whose expression in the double null mutant pollen tubes was shown to be either reduced or elevated, when compared to wild type pollen tubes. These genes can be used as starting points to dissect the gene regulatory networks in which AGPs are involved during pollen tube growth. In parallel, we performed yeast two-hybrid experiments to identify interactors of AGP6 and AGP11, and to provide evidence for the biological functions of these AGPs.

\section{Results}

An Arabidopsis line simultaneously null for two pollenspecific AGP genes, AGP6 and AGP11, has been characterized in our laboratory and found to display notable phenotypic alterations, namely partially aborted pollen grains, reduced germination potential and precocious germination inside the anthers [11,12]. Furthermore, under the conditions used in this study pollen tubes of the double mutant were statistically shorter $(83 \mu \mathrm{m})$ than those of the wild type $(100 \mu \mathrm{m})$.

To further characterize the agp6 agp11 mutant line a differential microarray screen was carried out to identify genes with modified expression in the 8 h-grown pollen tubes of agp6 agp11 compared to wild type pollen tubes.

\section{General data analysis}

The number of expressed genes in the wild type pollen tubes (as indicated by a minimum of 2 out of 3 Present calls in the triplicate GeneChip experiments) was found to be 6886 , which is approximately $28 \%$ of the total number of genes represented in the GeneChip Arabidopsis ATH1 Genome Array. This value is in close agreement with those published for microarray studies of Arabidopsis pollen tubes using the same type of microarray chips and experimental set up, i.e., in vitro-grown pollen tubes harvested $4-6 \mathrm{~h}$ post-germination $[5,6]$. Microarray data was published in GEO (http://www.ncbi.nlm.nih.gov/geo/info/ linking.html) with the record number GSE40861. 


\section{Functional classification of wild type pollen tube transcriptomes}

The transcriptome of wild type pollen tubes (6886 genes) was categorized into 34 functional groups according to the MapMan visualization software (Figure 1). Of the genes indicated as present, $28.7 \%$ had unknown functions, whereas the rest were primarily involved in protein synthesis (18.8\%), RNA transcription and processing (10.6\%), signaling (5.0\%), transport (5.0\%), and cell organization and cytoskeleton (4.9\%). This functional distribution is consistent with the recruitment of cell resources for pollen tube growth, and is in agreement with other pollen and pollen tube microarray studies $[4,5]$.

\section{Arabidopsis agp6 agp11 differentially expressed genes}

The number of genes expressed in the agp6 agp 11 mutant pollen tubes was roughly equal to that of the wild type control although only $87.5 \%$ of expressed genes were common to both data sets (Figure 2). There are two gene populations of specific interest; 1) those present only in the double mutant and 2) those present only in the wild type pollen tubes. However, a statistical analysis of the significantly differentially expressed genes necessarily produced a rather different population of genes from that shown in Figure 2. Genes were considered to be differentially expressed from those they were compared with if the 90\% lower confidence bound of the fold change between experiment and baseline was above 1.3, resulting in a median False Discovery Rate (FDR) of less than 5\%. Observing such criterion a population of 1022 differentially expressed genes was obtained which accounts for $14.7 \%$ of the pollen tube transcriptome (Figure 2 and Additional file 1). These 1022 genes included 155 genes present only in agp6 agp 11, 168 genes present only in wild type, and 699 genes expressed in both. About $60 \%$ of these 699 genes were up-regulated in agp6 agp11, with the remaining $40 \%$ being down-regulated. Overall the agp 6 agp $11 \mathrm{mu}-$ tation caused an up-regulation of over 500 genes in Arabidopsis pollen tubes.

\section{Validation of gene expression}

RNA levels were independently verified for a collection of genes, either by real-time PCR (qPCR) or by conventional semi-quantitative RT-PCR. Genes were selected on the basis of expression differences between the two microarray data sets and of absolute signal values (Table 1). The relative expression levels for all genes tested were consistent with the results of the microarray experiments, thus confirming its reliability.

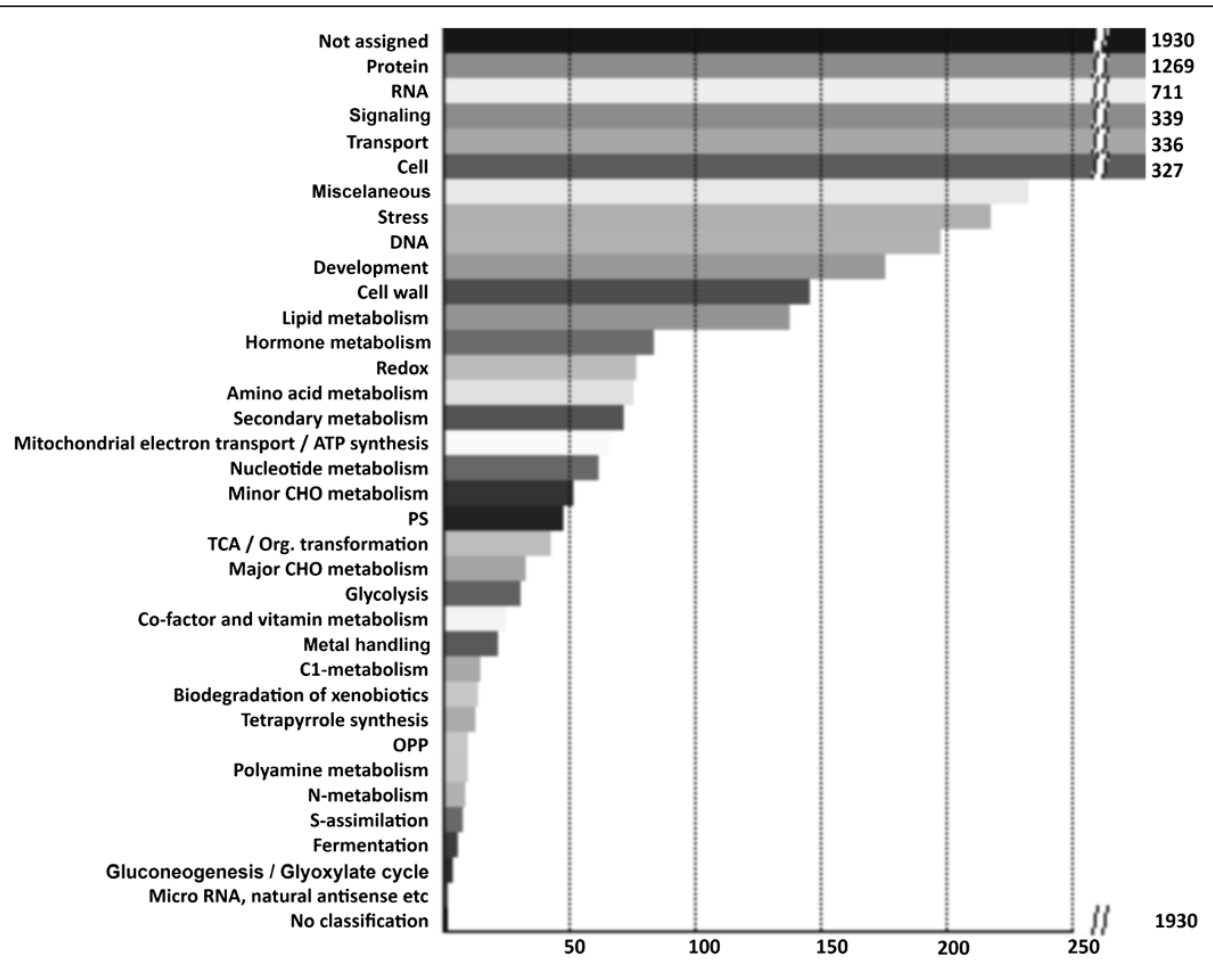

Figure 1 Functional classification of wild-type Arabidopsis pollen tube transcriptome. Analysis was performed with Classification SuperViewer Tool using MapMan source [13]. 


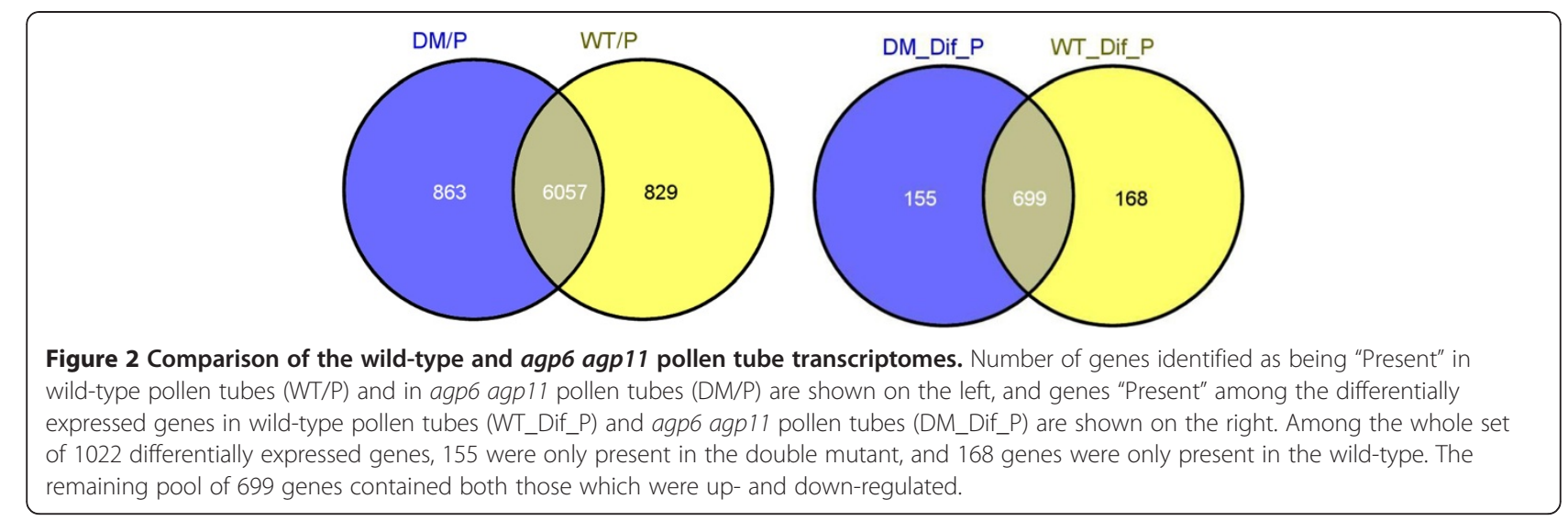

Functional classification of differentially expressed genes According to the MapMan classification software, the functional classification of the entire double mutant transcriptome, does not substantially diverge from the functional classification of the wild type transcriptome (Figure 1). However, a significant number of genes are differentially expressed, i.e. they are either up- or downregulated in response to the absence of two AGP gene products. The MapMan functional classification of these differentially expressed genes is shown in Figure 3.

The MapMan functional BINs "Protein", "RNA", "Transport", "Signaling", "Cell", "DNA, and "Stress" are the groups in which the greatest number of genes was altered, and together account for almost half of the differentially expressed genes (46\%).

A sub-cluster of the larger "Protein" cluster that contains genes with F-box motifs was particularly striking for its differential signal intensities and number of genes affected, with a representation factor of $1.8 \times$ relative to the Arabidopsis genome. Likewise, the sub-clusters "signaling. calcium", and "stress.abiotic.heat" show enrichment factors of $1.5 \times$ and $2.1 \times$, respectively, in the differentially expressed gene set, as compared to the whole genome. The sub-clusters "signaling.receptor.kinases" and "stress.

Table 1 Summary of confirmatory PCR assays

\begin{tabular}{|c|c|c|c|c|}
\hline Gene & AGI ID & LBFC $^{a}$ & $F C-q P C R^{b}$ & RT-PCR \\
\hline Ubiquitin-conjugating enzyme 20 & At1g50490 & +2.44 & +7.0 & \\
\hline Proline transporter 1 & At2g39890 & +2.02 & +2.0 & \\
\hline Zinc finger (C3HC4-type RING finger) family protein & At5g60250 & +1.96 & +4.0 & \\
\hline Sucrose phosphate synthase $2 \mathrm{~F}$ & At5g11110 & +1.70 & +1.5 & \\
\hline Expansin B5 & At3g60570 & +1.50 & +2.0 & \\
\hline CML42 & At4g20780 & +1.48 & +4.5 & \\
\hline Plant cadmium resistance 11 & At1g68610 & -1.99 & -2.0 & \\
\hline Cellulase 3 & At1g71380 & -1.98 & -1.4 & \\
\hline Phosphoinositide 4-kinase gamma 4 & At2g46500 & -1.75 & -2.2 & \\
\hline Heat shock protein $17.6 \mathrm{~A}$ & At1g53540 & -1.34 & -2.2 & \\
\hline CAP (Pathogenesis-related protein, putative) & At2g19970 & +23.34 & & + \\
\hline C2 domain-containing protein & At3g57880 & +16.93 & & + \\
\hline F-box family protein & At1g65760 & +11.8 & & + \\
\hline Beta glucosidase 36 & At1g51490 & +4.95 & & + \\
\hline CAP (allergen V5) & At2g19980 & +4.79 & & + \\
\hline Hypothetical protein & At2g22340 & -141.79 & & - \\
\hline Pentatricopeptide (PPR) & At5g28380 & -44.55 & & - \\
\hline Avirulence-responsive family protein & At4g09950 & -25.77 & & - \\
\hline DET3 & At1g12840 & -12.71 & & - \\
\hline
\end{tabular}

a Lower bound of fold change (microarray experiment).

b agp6 agp 11 to wild-type fold change for qPCR experiments.

c Genes up- or down-regulated in agp6 agp11, as assessed by semi-quantitative RT-PCR are indicated with a (+) or a (-) sign, respectively. 


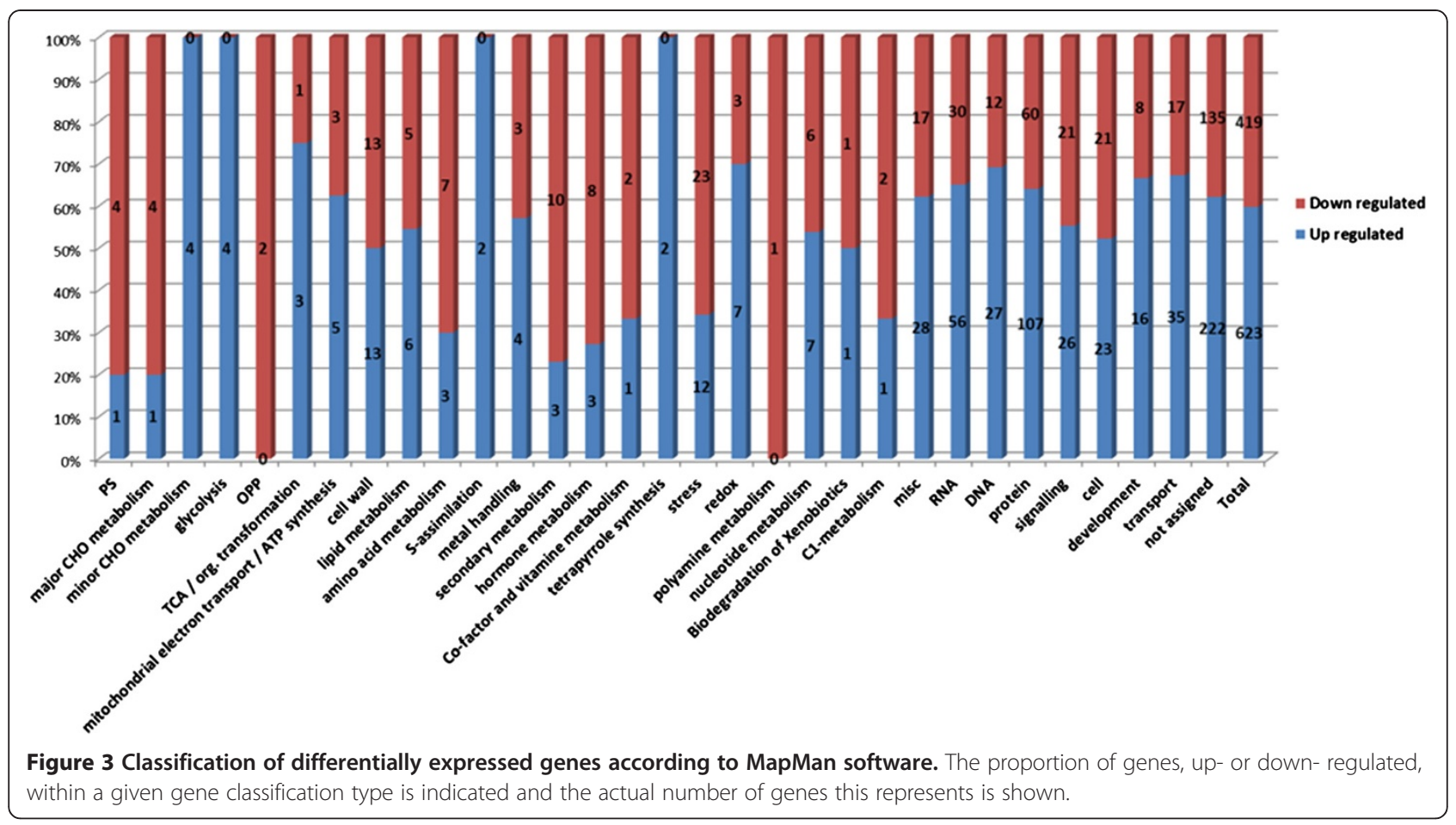

biotic" were not enriched in the differentially expressed group of genes but were selected because of the high LBFC value of some of its members (Table 2).

Another group of stress-related genes (CAP genes; Table 3) was also notable for their signal intensities and, in particular the large increase in the respective signal intensities of two of its members compared to wild type (Table 3).

To identify possible gene interactions and/or associations we used a Web interface (GeneMANIA) which is designed to analyze gene lists and prioritize genes for functional assays [15]. Extracting the differentially expressed genes from the list of 500 genes with the highest signal intensity, a gene network was produced that highlighted a "response to heat" gene cluster (Figure 4).

\section{AGP6 And AGP11 interactors detected by yeast-two hybrid assays}

To experimentally detect putative interactors for AGP6 and AGP11 we used the core domains of these two proteins as baits to screen a normalized Arabidopsis expression library. A whole plant cDNA library was used as it was thought to be the best choice for identifying AGP interactors. The library was generated from pools of cDNAs obtained by mRNA extracted from several organs at different developmental stages including developing inflorescences, developing siliques, and mature flowers just before, and at, anthesis. The library was normalised in order to achieve a better representation of low abundant messengers.
For the AGP6 library mating plates, 111 colonies grew on selective media. Forty-eight among them were selected randomly for sequencing and they revealed 37 unique possible candidates. The ones that had an absent call in our array experiment as well as in other publicly available pollen and pollen tube arrays [5-7] were excluded, resulting in a set of 22 likely candidates for interaction (Table 4). For the AGP11 library mating plates only 11 colonies grew on selective media and all were sequenced. Those resulted in 5 likely candidates for interaction (Table 4).

Of the putative interactors uncovered, four were selected to confirm interaction with AGP6 and one with AGP11: CaLB domain family protein (At1g70810), MAPK9 (At3g18040), UBQ10 (At4g05320) and FBR12 (At1g26630), and AP2C1 (At2G30020), respectively. All co-transformed colonies with the AGP and each candidate grew on all selective media, while each negative control did not, thus confirming the interaction (Figure 5).

\section{Discussion}

Sexual plant reproduction relies on the transfer of pollen to the stigma, where it hydrates and germinates into a pollen tube that extends through the pistil tissues to its target, the embryo sac. The agp6 agp11 double null mutant, besides showing a pollen tube growth defect also shows an early "inside the anther" germination phenotype. These deficiencies, provide further evidence for the role of AGPs in cell wall deposition and growth, and potentially represent a defect in receiving, or responding to, germination cues. 
Table 2 agp6 agp11 differentially expressed genes among the MapMan BINs [29.5.11.4.3.2: protein. degradation. ubiquitin. E3. SCF. F-box], [30.2: signaling.receptor kinases], [30.3: signaling.calcium], [20.1:stress.biotic], and [20.2.1: stress.abiotic.heat]

\begin{tabular}{|c|c|c|c|}
\hline MapMan BIN & AGI locus & LBFC $^{\mathrm{a}}$ & Gene annotation $^{\mathbf{b}}$ \\
\hline \multicolumn{4}{|c|}{ 29.5.11.4.3.2: protein. degradation. ubiquitin. E3. SCF. F-box } \\
\hline \multicolumn{4}{|l|}{ Up-regulated } \\
\hline & At1g65760 & 11.8 & Protein of unknown function (DUF295) \\
\hline & At2g27520 & 6.63 & F-box and associated interaction domains-containing protein \\
\hline & At5g38390 & 5.43 & F-box/RNI-like superfamily protein \\
\hline & At3g52030 & 3.92 & F-box family protein with WD40/MTN repeat domain \\
\hline & At2g24080 & 3.52 & Protein of unknown function (DUF295) \\
\hline & At5g27750 & 3.19 & F-box/FBD-like domains containing protein \\
\hline & At3g49520 & 2.79 & F-box and associated interaction domains-containing protein \\
\hline & At1g70360 & 2.65 & F-box family protein \\
\hline & At3g17710 & 2.40 & F-box and associated interaction domains-containing protein \\
\hline & At2g17020 & 2.25 & F-box/RNI-like superfamily protein \\
\hline & At3g13820 & 2.08 & F-box and associated interaction domains-containing protein \\
\hline & At2g03580 & 1.99 & F-box family protein-related \\
\hline & At5g03000 & 1.75 & Galactose oxidase/kelch repeat superfamily protein \\
\hline & At1g06630 & 1.71 & F-box/RNI-like superfamily protein \\
\hline & At3g50080 & 1.61 & VFB2, VIER F-box proteine 2 \\
\hline & At5g60610 & 1.55 & F-box/RNI-like superfamily protein \\
\hline & At3g18980 & 1.50 & EIN2 targeting protein1 (ETP1) \\
\hline & At3g59000 & 1.44 & F-box/RNI-like superfamily protein \\
\hline & At2g07120 & 1.38 & F-box associated ubiquitination effector family protein \\
\hline & At5g49610 & 1.36 & F-box family protein \\
\hline & At1g55590 & 1.35 & RNI-like superfamily protein \\
\hline & At1g23780 & 1.34 & F-box family protein \\
\hline \multicolumn{4}{|l|}{ Down-regulated } \\
\hline & At5g43190 & -7.32 & Galactose oxidase/kelch repeat superfamily protein \\
\hline & At1g68050 & -4.00 & "Flavin-binding, kelch repeat, F-box 1" \\
\hline & At1g12490 & -3.55 & F-box associated ubiquitination effector family protein \\
\hline & At1g55000 & -1.99 & Peptidoglycan-binding LysM domain-containing protein \\
\hline & At1g78840 & -1.96 & F-box/RNI-like/FBD-like domains-containing protein \\
\hline & At2g25490 & -1.58 & EIN3-binding F-box protein 1 \\
\hline & At4g04690 & -1.52 & F-box and associated interaction domains-containing protein \\
\hline & At1g70590 & -1.44 & F-box family protein \\
\hline \multicolumn{4}{|c|}{ 30.2: signaling. receptor kinases } \\
\hline \multicolumn{4}{|l|}{ Up-regulated } \\
\hline & At4g23280 & 2.27 & Cysteine-rich RLK (RECEPTOR-like protein kinase) 20 \\
\hline & At3g21970 & 2.22 & Domain of unknown function (DUF26) \\
\hline & At5g40380 & 1.33 & Cysteine-rich RLK (RECEPTOR-like protein kinase) 42 \\
\hline & At4g20790 & 1.76 & Leucine-rich repeat protein kinase family protein \\
\hline & At3g24550 & 1.61 & Proline extensin-like receptor kinase 1 \\
\hline & At4g28670 & 1.41 & Protein kinase family protein with domain of unknown function (DUF26) \\
\hline & At5g23170 & 1.35 & Protein kinase superfamily protein \\
\hline \multicolumn{4}{|l|}{ Down-regulated } \\
\hline & At4g20530 & -7.70 & Receptor-like protein kinase-related \\
\hline & At5g59650 & -3.61 & Leucine-rich repeat protein kinase family protein \\
\hline
\end{tabular}


Table 2 agp6 agp11 differentially expressed genes among the MapMan BINs [29.5.11.4.3.2: protein. degradation. ubiquitin. E3. SCF. F-box], [30.2: signaling.receptor kinases], [30.3: signaling.calcium], [20.1:stress.biotic], and [20.2.1: stress.abiotic.heat] (Continued)

\begin{tabular}{|c|c|c|c|}
\hline & At4g02420 & -2.87 & Concanavalin A-like lectin protein kinase family protein \\
\hline & At1g11280 & -2.01 & S-locus lectin protein kinase family protein \\
\hline & At1g61380 & -1.73 & S-domain-1 29 \\
\hline \multicolumn{4}{|c|}{ 30.3: signaling. calcium } \\
\hline \multicolumn{4}{|l|}{ Up-regulated } \\
\hline & At1g18890 & 2.66 & Calcium-dependent protein kinase 1 \\
\hline & At5g19360 & 2.30 & Calcium-dependent protein kinase 34 \\
\hline & At5g62390 & 1.57 & BCL-2-associated athanogene 7 \\
\hline & At4g20780 & 1.48 & Calmodulin-like 42 Calcium; sensor involved in trichome branching \\
\hline & At1g05150 & 1.44 & Calcium-binding tetratricopeptide family protein \\
\hline & At5g42380 & 1.40 & Calmodulin-like 37 \\
\hline & At1g51960 & 1.38 & IQ-domain 27 \\
\hline & At5g47100 & 1.31 & Calcineurin B-like protein 9 \\
\hline \multicolumn{4}{|c|}{ Down-regulated } \\
\hline & At1g18530 & -1.89 & EF hand calcium-binding protein family \\
\hline & At5g55990 & -1.88 & Calcineurin B-like protein 2 \\
\hline & At2g33990 & -1.68 & IQ-domain 9 \\
\hline & At1g62480 & -1.54 & Vacuolar calcium-binding protein-related \\
\hline & At2g41410 & -1.48 & Calcium-binding EF-hand family protein \\
\hline & At4g34150 & -1.33 & Calcium-dependent lipid-binding (CaLB domain) family protein \\
\hline \multicolumn{4}{|c|}{ 20.1: stress. biotic } \\
\hline \multicolumn{4}{|l|}{ Up-regulated } \\
\hline & At2g19970 & 23.34 & CAP (Cysteine-rich secretory proteins, Antigen 5, and Pathogenesis-related 1 protein) superfamily protein \\
\hline & At3g02840 & 2.56 & ARM repeat superfamily protein \\
\hline & At4g16920 & 2.52 & Disease resistance protein (TIR-NBS-LRR class) family \\
\hline & At1g32210 & 1.78 & Defender against death (DAD family) protein \\
\hline & At2g35520 & 1.77 & Defender against death (DAD family) protein \\
\hline \multicolumn{4}{|c|}{ Down-regulated } \\
\hline & At4g09950 & -25.77 & P-loop containing nucleoside triphosphate hydrolases superfamily protein \\
\hline & At3g44400 & -6.01 & Disease resistance protein (TIR-NBS-LRR class) family \\
\hline & At4g16860 & -4.48 & Disease resistance protein (TIR-NBS-LRR class) family \\
\hline & At1g75040 & -2.63 & Pathogenesis-related gene 5 \\
\hline & At3g18690 & -1.88 & MAP kinase substrate 1 \\
\hline & At1g14530 & -1.82 & TOM THREE HOMOLOG 1 (THH1); Protein of unknown function DUF1084 \\
\hline & At1g58170 & -1.59 & Disease resistance-responsive (dirigent-like protein) family protein \\
\hline & At2g25240 & -1.41 & Serine protease inhibitor (SERPIN) family protein \\
\hline \multicolumn{4}{|c|}{ 20.2.1: stress. abiotic. heat } \\
\hline \multicolumn{4}{|l|}{ Up-regulated } \\
\hline & At1g28210 & 2.40 & DNAJ heat shock family protein \\
\hline & At3g22530 & 1.97 & Unknown protein \\
\hline & At1g72070 & 1.50 & Chaperone DnaJ-domain superfamily protein \\
\hline \multicolumn{4}{|c|}{ Down-regulated } \\
\hline & At2g29500 & -4.93 & HSP20-like chaperones superfamily protein \\
\hline & At3g46230 & -1.92 & Heat shock protein 17.4 \\
\hline & At5g12030 & -1.84 & Heat shock protein $17.6 \mathrm{~A}$ \\
\hline & At1g79920 & -1.84 & Heat shock protein 70 (Hsp 70) family protein \\
\hline
\end{tabular}


Table 2 agp6 agp11 differentially expressed genes among the MapMan BINs [29.5.11.4.3.2: protein. degradation. ubiquitin. E3. SCF. F-box], [30.2: signaling.receptor kinases], [30.3: signaling.calcium], [20.1:stress.biotic], and [20.2.1: stress.abiotic.heat] (Continued)

\begin{tabular}{lll}
\hline At1g59860 & -1.78 & HSP20-like chaperones superfamily protein \\
\hline At5g22060 & -1.65 & DNAJ homologue 2 \\
\hline At1g71000 & -1.49 & Chaperone DnaJ-domain superfamily protein \\
\hline At2g03020 & -1.49 & Heat shock protein HSP20/alpha crystallin family \\
\hline At4g13830 & -1.43 & DNAJ-like 20 \\
\hline At5g02500 & -1.41 & Heat shock cognate protein 70-1 \\
\hline At1g53540 & -1.34 & HSP20-like chaperones superfamily protein
\end{tabular}

\footnotetext{
agp6 agp11 to wild type lower bound of fold change.
}

b TAIR annotations [14].

AGPs are a class of molecules whose study has been particularly challenging. More than $90 \%$ of the molecular mass is carbohydrate (predominantly consisting of arabinose and galactose residues), and the role of the polypeptide chain, if any, is unknown. Moreover, how the sugar content and quality varies between different gene products, and whether different gene products are identically glycosylated is equally poorly characterised. A direct consequence of this is that techniques and approaches used to study proteins often do not apply to AGPs. The massive sugar component which surrounds the protein core is likely to have a biological role but its biological interactions and mechanism of action have so far eluded characterisation. Phenotypic differences between wild type and double mutant pollen tubes can only be attributed to the lack of both AGP6 and AGP11. It is impossible to determine whether the differential gene expression is due to a direct effect of the lack of AGPs on the expression of these genes, or whether the altered expression profile is a secondary and unspecific consequence of the reduction in growth rate. However, an expression-based study should improve our understanding of AGPs and their functionality by identifying genes that are altered in response to the lack of specific AGPs. This type of investigation is likely to be particularly informative when applied to a process known to involve AGPs, in a plant structure, the pollen tube, whose transcriptome is less than a third of the genome.

This study yielded a number of candidate genes that may directly or indirectly interact with AGPs and have a role in pollen tube growth. However, a comparative analysis of the present data with the expression profile of Arabidopsis culture cells subjected to Yariv phenylglycoside reagent, which specifically binds to and precipitates AGPs [44-48], was considered to be a valuable aid to the identification of genes which may be directly affected by the lack of AGP6 and AGP11.

\section{Microarray screen}

The overall difference obtained for expressed genes was substantial, with 1022 differentially expressed genes in the double null mutant, compared with the wild type control. These 1022 differentially expressed genes could be further classified into three subgroups: 155 genes that were expressed "de novo" in the double mutant, 168 genes that were absent in the mutant but present in the control, and a group of 699 genes whose expression levels were found to be altered but that did not affect the present/absent status.

The gene clustering using MapMan software shows that the cluster "Protein" contains the largest fraction of differentially expressed genes. "Protein degradation" is undoubtedly the most represented group, in which the category of ubiquitin-mediated protein degradation is evident, with several of those genes belonging to the F-Box protein family. The F-box is a protein motif of approximately 50 amino acids that function as a site for protein-protein interaction [49]. Arabidopsis alone was reported to contain approximately $700 \mathrm{~F}$-Box genes [50]. By comparison, only 20, 27, and 69 F-Box proteins are encoded by Saccharomyces cerevisiae, Drosophila melanogaster, and human genomes, respectively [51]. Such an apparent massive investment has also been found to be consistent with genetic studies linking specific plant FBox proteins to numerous processes, including hormone perception and signaling, stress protection, chromatin remodeling, homeostasis, circadian rhythms, self-incompatibility, and defense against pathogens [52]. In Arabidopsis, recent genetic studies provided unequivocal evidence for the role of this protein degradation system during gametogenesis, which involved F-Box 17 [53] and a pair of ubiquitin-specific proteases (UBP3/UBP4) [54].

The analysis of the data obtained in the present work also shows calmodulins (CaMs), in the cluster of signaling by calcium, among the differentially expressed genes with highest LBFC score, namely At5g24880 and At4g20780 (CML42), the latter functioning in trichome branching and being strongly expressed in pollen as shown by CML42::GUS transgenic plants [55]. Calcium signals are known to play important roles in plant growth and development, including pollen tube growth, 
Table 3 Summary of expression data for genes belonging to the CAP (Cysteine-rich secretory proteins, Antigen 5, and Pathogenesis-related 1 protein) superfamily protein

\begin{tabular}{lcccccc}
\hline AGl locus & agp6 agp11 signal & Wild type signal & LBFC $^{\mathbf{a}}$ & Wild type call $^{\mathbf{b}}$ & Pollen tube call $^{\text {Pollen specificity }}$ \\
\hline At2g19970 & 299 & 7.5 & +23.0 & $\mathrm{~A}$ & $\mathrm{~A}$ & No \\
\hline At2g19980 & 5622 & 887 & +4.8 & $\mathrm{P}$ & $\mathrm{P}$ & Yes \\
\hline At3g19690 & 4785 & 4400 & $<1.3$ & $\mathrm{P}$ & $\mathrm{P}$ & Yes \\
\hline At1g01310 & 5490 & 4100 & $<1.3$ & $\mathrm{P}$ & $\mathrm{P}$ & Yes \\
\hline At4g25780 & 4578 & 4036 & $<1.3$ & $\mathrm{P}$ & $\mathrm{P}$ & Yes \\
\hline At3g09590 & 1367 & 1395 & $<1.3$ & $\mathrm{P}$ & $\mathrm{P}$ & No \\
\hline At5g02730 & 672 & 686 & $<1.3$ & $\mathrm{P}$ & $\mathrm{P}$ & No \\
\hline
\end{tabular}

agp6 agp11 to wild type lower bound of fold change.

${ }^{\mathrm{b}} \mathrm{A}=$ absent; $\mathrm{P}=$ present.

and $\mathrm{CaMs}$ are the most ubiquitous calcium sensors in eukaryotes. Popescu et al. [56] developed a protein microarray to comprehensively investigate Arabidopsis CaM/ CaM-like interactions and identified new targets for these calcium sensors, one of which was an F-Box protein. The relationship between AGPs and calcium is unsurprising, as these proteins are involved in pollen tube cell wall growth, and calcium is known to regulate pollen tube growth and fertilization [57]. The data obtained may suggest an interaction of AGPs with calcium through calmodulin. This was also implied using an alternative approach to study AGP function which involved the use of ( $\beta$-D-Glc)-3 Yariv reagent that specifically binds to, and presumably inactivates, a wide range of AGPs. Guan and Nothnagel [44] analyzed the gene expression profile of Arabidopsis culture cells subjected to Yariv phenylglycoside reagent for 1 and $10 \mathrm{~h}$ in a microarray study. Despite the specificities of the biological materials, several differentially expressed genes were found to be common between both experiments (Additional file 2). The values of LBFC used in the present work could not be used for direct comparison with the data of Guan and Nothnagel [44]. However, all values of fold change of agp 6 agp11 genes shown in Additional file 2, have values of LBFC above the

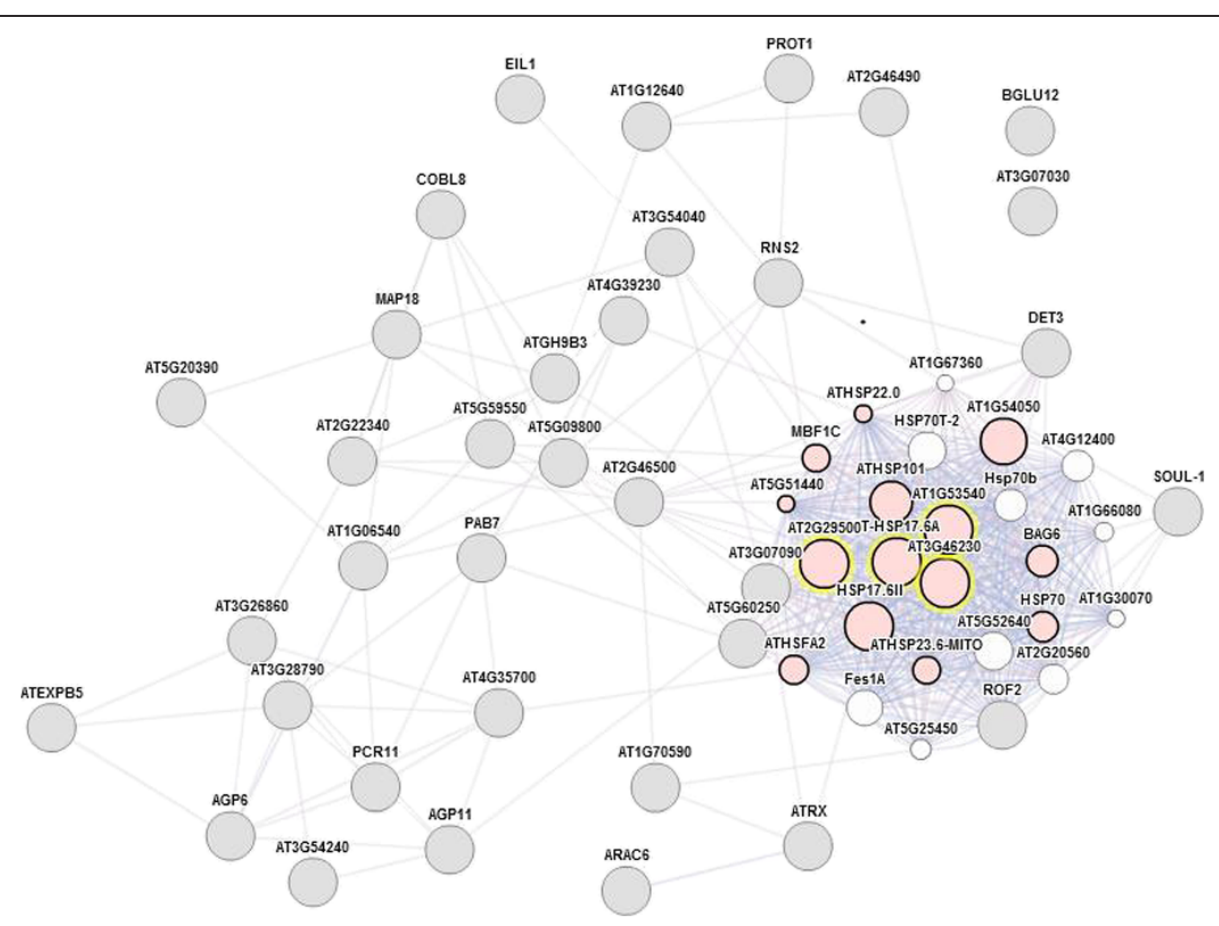

Figure 4 Heat shock protein genes are differentially expressed in the agp6 agp11 pollen tubes. The internet tool GeneMANIA was Used to produce a gene association network. The input data was all the differentially expressed genes isolated from the 500 genes with highest signal intensities in the wild-type microarray data set. Some of those genes (At1g53540, HSP20-like chaperones superfamily protein; At3g46230, 17.4 kDa class I heat shock protein; At5g12030, heat shock protein 17.6A; At2g29500, HSP20-like chaperones superfamily protein) belong to a "response to heat" functional cluster (pink circles) [15]. 
Table 4 Interactors of AGP6 and AGP11 identified by Yeast two-Hybrid library screening assays

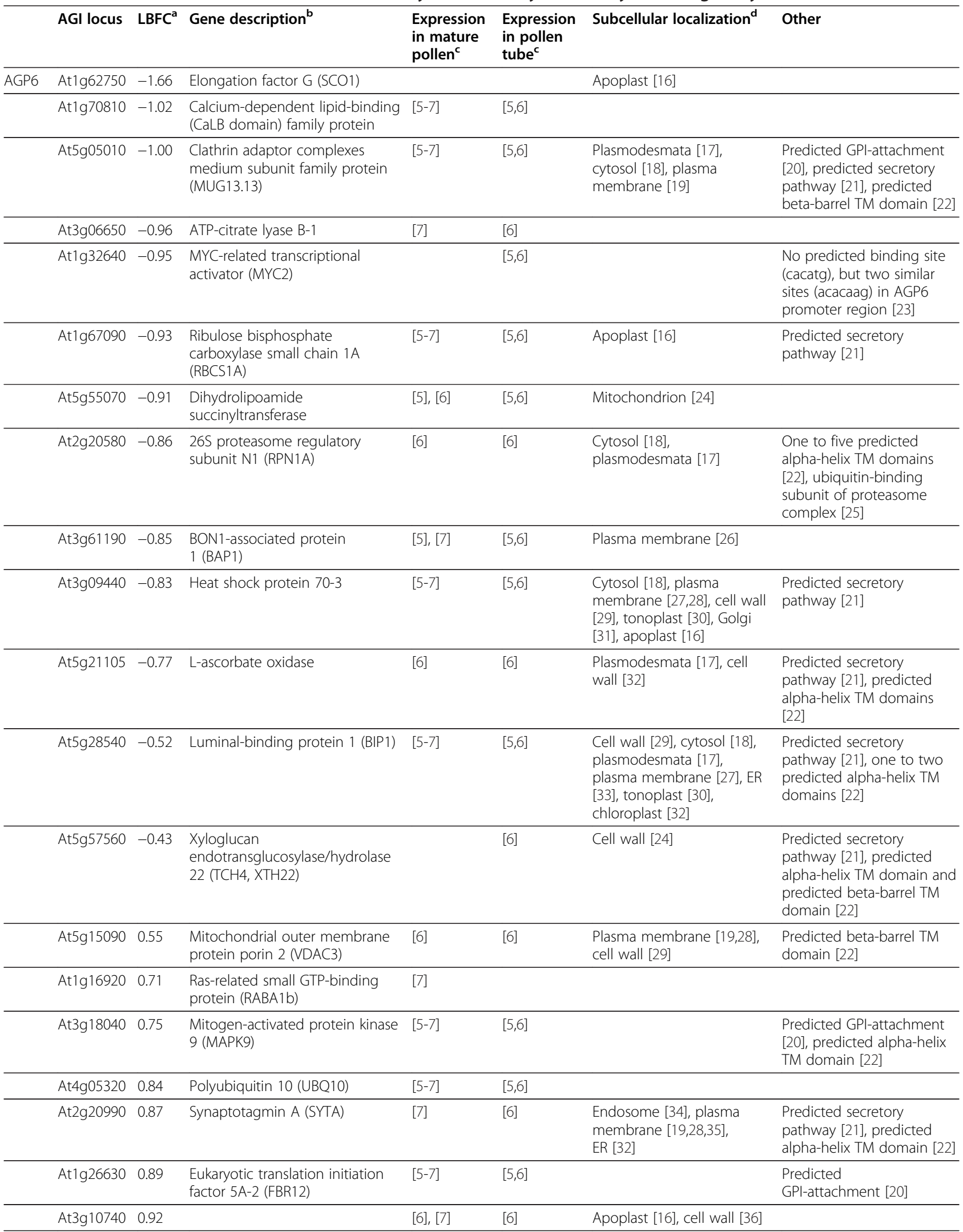


Table 4 Interactors of AGP6 and AGP11 identified by Yeast two-Hybrid library screening assays (Continued)

\begin{tabular}{|c|c|c|c|c|c|c|c|}
\hline & & & \multicolumn{4}{|l|}{$\begin{array}{l}\text { Alpha-L-arabinofuranosidase } \\
1 \text { (ASD1) }\end{array}$} & \multirow{2}{*}{$\begin{array}{l}\text { Predicted secretory } \\
\text { pathway [21], one to two } \\
\text { predicted alpha-helix } \\
\text { TM domains [22] }\end{array}$} \\
\hline & At5g11200 & 1.22 & $\begin{array}{l}\text { DEAD-box ATP-dependent } \\
\text { RNA helicase } 56\end{array}$ & {$[6]$} & {$[5,6]$} & $\begin{array}{l}\text { Cell wall [29], } \\
\text { plasmodesmata [17] }\end{array}$ & \\
\hline & At1g31150 & 2.50 & Uncharacterized protein & [7] & & & $\begin{array}{l}\text { Predicted secretory } \\
\text { pathway [21], predicted } \\
\text { alpha-helix TM domain [22] }\end{array}$ \\
\hline \multirow[t]{5}{*}{ AGP11 } & At3g47810 & -1.43 & $\begin{array}{l}\text { MAG1 Homolog of yeast } \\
\text { retromer subunit VPS29 }\end{array}$ & {$[5-7]$} & {$[5,6]$} & $\begin{array}{l}\text { Multivesicular body [37], } \\
\text { endosome [38] }\end{array}$ & $\begin{array}{l}\text { Mediator of protein } \\
\text { targeting to vacuole [39] }\end{array}$ \\
\hline & At1g42990 & -0.97 & $\begin{array}{l}\text { bZIP transcription factor } \\
60 \text { (BZIP60) }\end{array}$ & {$[5-7]$} & {$[5,6]$} & & $\begin{array}{l}\text { Predicted GPI-attachment } \\
\text { [20], predicted alpha-helix } \\
\text { TM domain [22] }\end{array}$ \\
\hline & At1g32640 & -0.95 & $\begin{array}{l}\text { MYC-related transcriptional } \\
\text { activator (MYC2) }\end{array}$ & & {$[5,6]$} & & $\begin{array}{l}\text { Two predicted binding } \\
\text { sites in AGP11 promotor } \\
\text { region [23] }\end{array}$ \\
\hline & At2g19070 & -0.63 & $\begin{array}{l}\text { Spermidine hydroxycinnamoyl } \\
\text { transferase (SHT) }\end{array}$ & & & & $\begin{array}{l}\text { Tapetum-specific [40], } \\
\text { involved in exine formation } \\
{[40,41]}\end{array}$ \\
\hline & At2g30020 & 0.74 & $\begin{array}{l}\text { Putative protein phosphatase } \\
\text { 2C } 25\end{array}$ & {$[5-7]$} & {$[5,6]$} & $\begin{array}{l}\text { Nucleus }[42,43] \\
\text { cytoplasm }[43]\end{array}$ & \\
\hline
\end{tabular}

threshold of 1.3, which was the criterion used in our analysis. Genes altered in Yariv-treated cells also include several heat-shock protein genes, which is a functional group also found to be affected in agp6 agp11.

Comparative pistil transcriptome analyses [58,59] identified a number of genes encoding proteins potentially involved in stress and defense responses. This is particularly interesting as there is evidence that the molecules involved in pollination and stress/defense responses may be evolutionary and functionally related. Many authors have proposed that certain self-incompatibility mechanisms may have arisen through the modification of preexisting pathogen defense mechanisms [60].

The analysis of the stress cluster of the present data shows that the genes associated with biotic and abiotic types of stress, namely PR and heat shock protein genes, had their expression levels significantly shifted. In this cluster, genes such as At2g19970 and At2g19980 code for proteins of the CAP (cysteine-rich, antigen 5 and pathogen-related 1 protein) superfamily. Members of the CAP superfamily are widespread in living organisms, [61], and have been intensely studied in mammalian fertilization mechanisms. They are most often secreted proteins and are involved in several processes including cell adhesion during fertilization. The plant pathogenesis proteins of the PR-1 family, which are synthesized during pathogen infection or other stress-related responses, belong to the CAP superfamily but the precise functions of these proteins are still unresolved. In a recent study
[62] it was suggested that the glioma pathogenesisrelated 1 (GLIPR1L1), along with other members of the CAP superfamily and several other proteins, are involved in the binding of sperm to the oocyte complex. Also, in a work of microarrays of rice embryo sac cells [63], it was revealed that allergen $\mathrm{V} 5 / \mathrm{Tpx}-1$-related proteins, which are members of the CAP superfamily, are abundant in the rice synergid cell. Collectively these findings strengthen the possible role of CAP domain-containing proteins in cellular adhesion and fertilization.

The high level of expression of 7 members of the CAP superfamily in Arabidopsis pollen tube is relevant given their predicted signaling function. Moreover, knowing that these proteins are most likely secreted and the fact that one of its members (At2g19970) is only present in the agp6 agp11 double mutant, may indicate some type of relationship between AGPs and CAP processing.

Application of a different bioinformatic tool, GeneMania, a co-expression network was obtained which highlighted a stress functional gene cluster. Surprisingly, some of the genes correlated with those whose expression was found to be altered by treatment with Yariv reagent for 10 h (At2g29500, At3g46230, At1g53540 and At5g12030) [44]. Guan and Nothnagel [44] compared the genes that were induced by Yariv treatments with genes whose expression had been previously been shown to be induced by other conditions and concluded that the gene expression profile induced by Yariv treatment was similar to that of wound response. Knowing that pollen tube growth and 


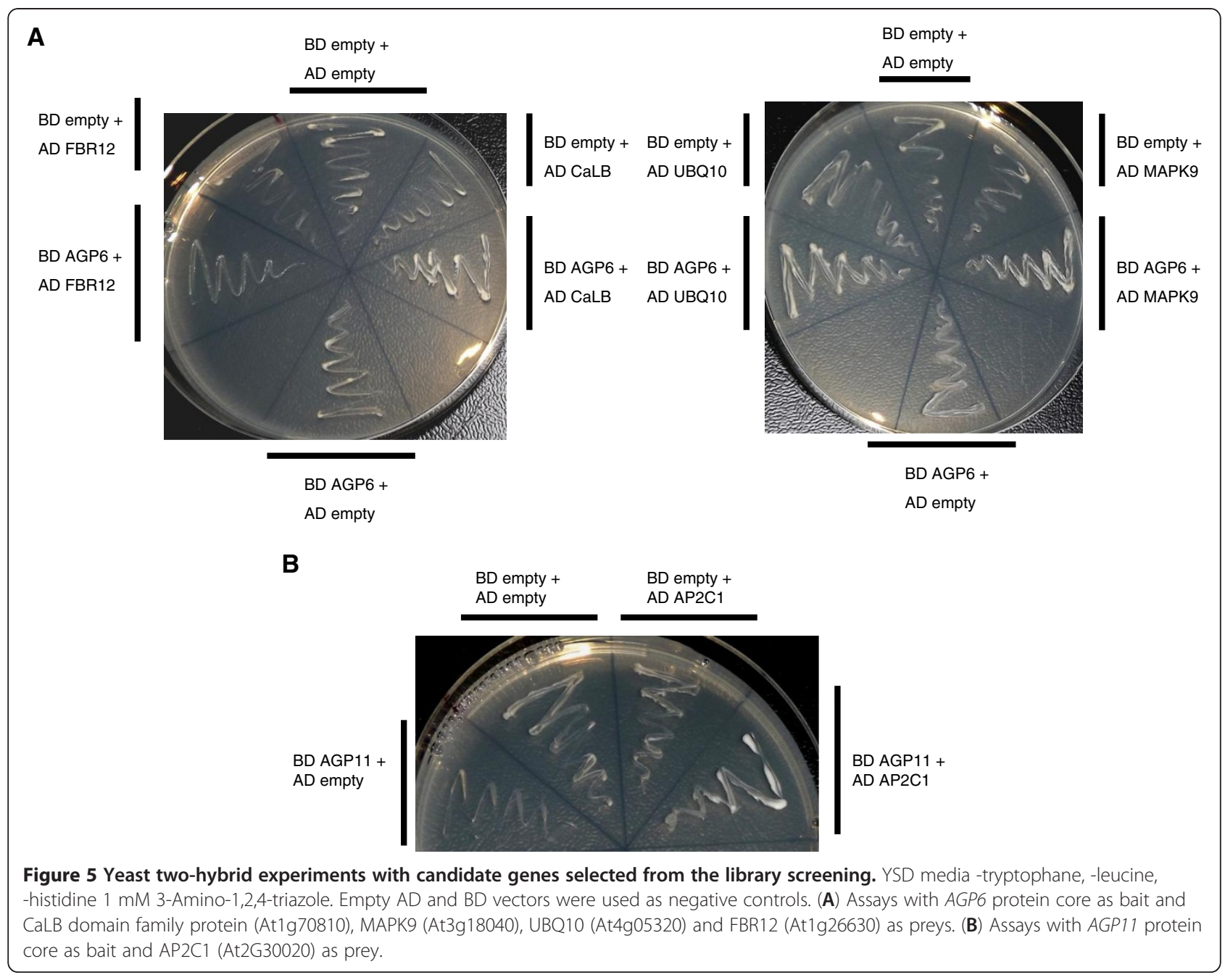

discharge and the defense against fungal attack are alike in many respects, and that both pollen tubes and fungi exploit similar receptor proteins $[64,65]$ we propose a role for AGPs in this process where, apparently, pollen tube and fungal hyphae activate plant cell responses.

\section{Yeast two-hybrid experiments}

To identify possible AGP6 and/or AGP11 interactors, yeast two-hybrid experiments were performed. These experiments revealed some interesting partners involved in the proteosome-independent roles of ubiquitination in signaling and endocytosis.

Besides the well-known role in proteosome degradation, ubiquitin conjugation is also involved in down-regulation of membrane receptors, transporters and channels. Ubiquitination of plasma membrane proteins leads to their endocytosis into the multivesicular endosome and most members of the ubiquitin ligase family responsible for trafficking of diverse proteins carry an N-terminal calciumdependent lipid/protein $\mathrm{C} 2$ domain that specifically binds phosphoinositides in yeast $[66,67]$.
Endosomes are primarily intracellular sorting organelles, and receive proteins and lipids from both the biosynthetic and the endocytic pathways. Plasma membrane proteins that are internalized by endocytosis are either recycled back to the plasma membrane or sorted for degradation, which is achieved by intermediate/late endosomes, also called multivesicular bodies (MVBs) [68,69].

It is known that pollen tubes grow by rapid tip localized exocytosis, most probably coordinated with an also tip localized endocytosis. Using Arabidopsis and Nicotiana pollen tubes as models, Zhao et al. [70] showed that phosphatidylinositol-4-phosphate 5-kinase 6 (PIP5K6) regulates clathrin-dependent endocytosis in pollen tubes.

The internalization and secretion of arabinogalactanrich glycoproteins through MVBs has been described but only microscopically [71,72]. The data obtained in the present study suggests a physiological interaction of AGPs with members of the endosomal system, and that AGP6 and AGP11, two specific and highly expressed proteins in Arabidopsis pollen and pollen tubes may be involved in this signaling pathway that sends and recycles 
proteins to the extracellular matrix. In the yeast twohybrid screening assays, clathrin adaptor complexes were present such as MUG13.13 and MAPK9, SYTA (a transmembrane protein involved in membrane trafficking), RABA1b (a small GTP binding protein also involved in intracellular protein trafficking) and MAG1 (a homolog of the yeast retromer subunit VPS29). These results give further support for the clathrin machinery of receptor internalization in pollen tubes.

Although AGPs are presumably acting extracellularly, they are targeted to the outer leaflet of the plasma membrane through vesicles, which originate in the ER and Golgi network. During the trafficking into the extracellular matrix it is probable that AGPs interact with cytosolic proteins such as bZIP60 or FBR/eIF5A, two regulatory proteins that were identified in the yeast two-hybrid experiments.

With endocytosis established as an essential plant cell function [69] and AGP6 and AGP11 supposedly involved in this process, we looked further into the microarray data. Three Rab GTPases known as specific molecular markers of plant endosomes, Ara6 (At3g54840), Ara7 (At4g19640) and Rha1 (At5g45710, also a member of the heat stress transcription factor family) are all downregulated in agp6 agp11. RabA2 (At3g46830) and RabA3 GTPases define a trans-Golgi endosomal membrane that overlays with VHA-a1 (At2g28520) one of the isoforms of a membrane integral V-ATPase specifically localized to the TGN [73]. Another subunit of V-ATPases, DET3, is one of the most down-regulated genes in the present study and known to be involved in plant growth and development [74].

A C2 domain is a protein structural domain involved in targeting proteins to cell membranes. C2 domains are modular lipid-binding domains found in a variety of proteins with functions that include vesicular transport, GTPase regulation, lipid modification, protein phosphorylation, and ubiquitylation [75]. The most extensively studied proteins included in the last group are the synaptotagmins (SYT). There are reports describing the involvement of C2-domain proteins in plant responses to abiotic and biotic stresses. Yang et al. [26,76] showed that the Arabidopsis C2-domain protein, BAP1, acts as a negative regulator of programmed cell death induced by biotic stimuli. This gene is differentially expressed in the present microarray experiment and in the Yariv microarray experiment described by Guan and Nothnagel [44]. The third most up-regulated gene in the present data set is a calcium-dependent lipid binding protein, CaLB (At3g57880), a C2 protein which is also up-regulated in the Yariv array. It seems relevant to highlight that the C2 calcium-dependent membrane targeting protein At1g70810 was identified as an AGP6 interactor in the yeast-two hybrid assay. Furthermore, in a yeast two-hybrid assay performed on Nicotiana alata [77] to identify pollen proteins potentially involved in deciphering chemical signals provided by the pistil, two pistil-specific AGPs from the transmitting tract were used to hybridize against a pollen cDNA library. The authors found three pollen proteins that interacted with those pistil AGPs, one of which was a $\mathrm{C} 2$ domain-containing protein (NaPCCP).

Analysis of the present results further identified a possible involvement of AGP6 and AGP11 in membrane trafficking, and that a plant retromer may be present in pollen tubes where the movement of vesicles is very important. A retromer is a multiprotein complex that is strongly conserved in eukaryotes. It is involved in the recycling of transmembrane receptors, which mediate the transport of vacuolar/lysosomal hydrolases [78]. In yeast, retromers consist of a large subunit with three vacuolar protein sorting (VPS) proteins, VPS35p, VPS29p and VPS26p. Homologs of these proteins are present in mammals and in plants. Recently, Oliviusson et al. [37] showed that the three VPS proteins, namely VPS35 (At3g51310), VPS29 (At3g47810), and VPS26 (At5g53530) of the plant retromer complex are localized to multivesicular bodies (MVBs) in tobacco BY2 cells. MAG1, a homolog of VPS29, is differentially expressed in the present array, as is VPS26. Besides, VPS29 is also differentially expressed in the Yariv microarray data and MAG1 is one of the AGP11 interactors in the yeast-two hybrid experiment. Recent data strongly suggest that the retromer complex has conserved a function in mediating retrograde trafficking [38] and that VPS29 is involved in the cycling of certain PM proteins and required for the establishment of cell polarity during organ initiation in plants [66].

A working model for the role of AGPs in pollen tube development which integrates the data obtained in this work is proposed (Figure 6).

\section{Conclusions}

It is known that plant cells recycle pectins and AGPs [80]. Pectin cross-linking calcium may be removed and pectins recycled, maintaining the loosened walls essential for growth. AGPs can also be recycled, to maintain their concentration level at the pollen tube apex necessary for them to perform a signaling role.

All the data obtained in the present work emphasizes the remodeling of the plasma membrane via endocytosis. Endosomal trafficking pathways are emerging as fundamental regulators of the wall physiology, involved in multiple signaling pathways and developmental processes. The interaction of AGP6 and AGP11 with members of the pollen tube endosome machinery provides strong evidence for the recycling of these cell wall proteins (Figure 6).

It is our understanding that as we continue to unravel the signal transduction processes involved in intercellular 

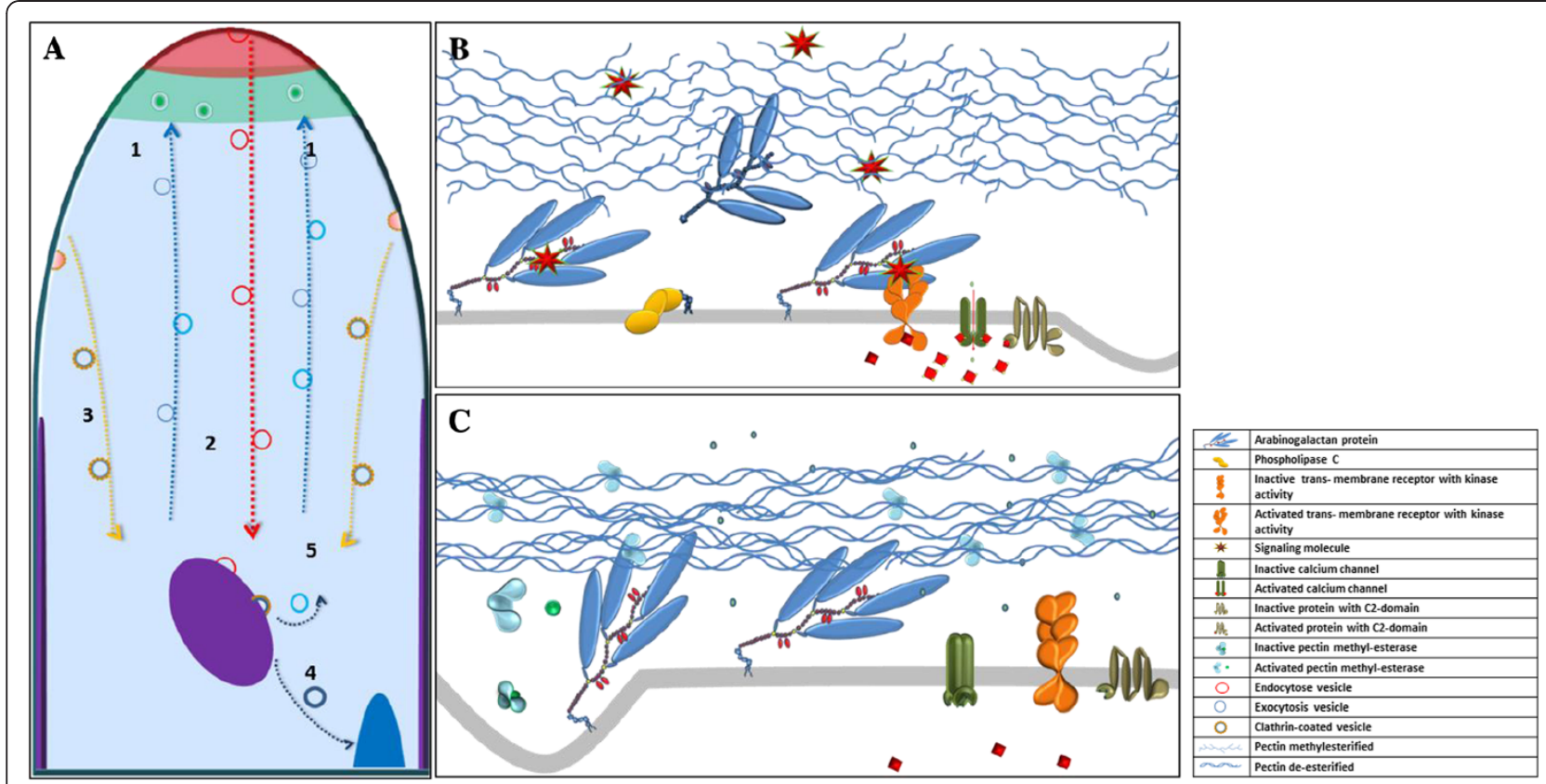

Figure 6 A model for the role of AGPs in pollen tube growth. (A) Accepted model for pollen tube growth [70,79], illustrating vesicle exocytosis (1), smooth endocytosis (2), clathrin vesicle endocytosis (3), the pathway into degradation (4) and the recycling pathway (5). The apical dome (red), the exocytosis region (green), the multivesicular body (purple) and the vacuole (blue) are shown. (B) Proposed model for AGP signaling role in the pollen tube apical dome. AGPs act as receptors for extracellular signals and interact with transmembrane proteins, possibly receptor kinases or C2 domain-containing proteins. These interactions lead to opening of calcium channels, triggering various intracellular events. During pollen tube growth, AGPs are recycled by endocytosis, and either reused or sent for degradation, through multivesicular bodies. (C) Proposed model for the sub-apical zone. The hardening of cell wall pectins resulting from complexing with calcium hinders AGP contact with putative signal molecules, rendering AGPs inactive.

communication during pollen/pistil interaction, we will discover more about the function of AGPs.

\section{Methods}

\section{Plant material and growth conditions}

A Ds-tagged agp6 agp11 homozygous double null mutant line [11] obtained from crossing RIKEN lines Ds54-4754-1 and Ds11-4025-1 (RIKEN GSC Arabidopsis Ds transposon tag line collection, [81]), was used for pollen harvest and plants from the ecotype Nossen (No-0 Line N3081 NASC) were used as control. All plants were germinated and grown in half strength Murashige and Skoog (MS) medium complemented with $0.7 \%$ agar. Plantlets were then transferred to soil and kept in a growth chamber at $22^{\circ} \mathrm{C}$ under long days ( $16 \mathrm{~h}$ light $/ 8 \mathrm{~h}$ dark), irradiance of $130 \mu \mathrm{mol} \mathrm{m}^{-2} \mathrm{~s}^{-1}$ and $60 \%$ relative humidity.

\section{Pollen isolation and pollen tube culture}

Pollen was collected from newly opened flowers and germinated according to Dardelle et al. [82]. Forty open flowers of Arabidopsis were introduced in each $1.5 \mathrm{~mL}$ microtube, and gently vortexed with $1 \mathrm{~mL}$ of pollen growth medium $\left(5 \mathrm{mM} \mathrm{KCl}, 5 \mathrm{mM} \mathrm{CaCl}_{2}, 1 \mathrm{mM} \mathrm{MgSO}_{4}\right.$, $0.01 \% \mathrm{H}_{3} \mathrm{BO}_{3}, 10 \%$ Sucrose, $\mathrm{pH} 7.4$ ) for $5 \mathrm{~min}$. The flowers were then removed with forceps, the microtubes centrifuged for $3 \mathrm{~min}$ at $3000 \mathrm{rpm}$ and the supernatant discarded. The pelleted pollen destined for pollen tube culture was combined in groups of three and resuspended in $1.25 \mathrm{~mL}$ of fresh pollen growth medium. The preparation was then transferred to $20 \mathrm{~mm}$ diameter flat bottom flasks and incubated at $22^{\circ} \mathrm{C}$ in the dark for $8 \mathrm{~h}$. The germinated pollen tubes were then washed through a $60 \mu \mathrm{m}$ mesh nylon net filters (Millipore NY6004700) with growth medium in order to discard ungerminated pollen grains. Pollen tubes from approximately 1600 flowers were used to obtain each independent replicate for agp6 agp11 and for wild type.

\section{RNA isolation, target synthesis and hybridization to affymetrix GeneChips}

Total RNA was extracted using the RNeasy Mini Kit (Qiagen, Hilden, Germany). Concentration and purity was determined by spectrophotometry and integrity was confirmed using an Agilent 2100 Bioanalyzer with a RNA 6000 Nano Assay (Agilent Technologies, Palo Alto, CA).

RNA was processed for use on Affymetrix (Santa Clara, CA, USA) GeneChip Arabidopsis ATH1 Genome Arrays, according to the manufacturer's GeneChip 3/ IVT Express kit user manual. Briefly, 100 ng of total RNA containing spiked in Poly-A RNA controls was used in a reverse 
transcription reaction (GeneChip 3/ IVT Express Kit; Affymetrix) to generate first-strand cDNA. After secondstrand synthesis, double-stranded cDNA was used in a $16 \mathrm{~h}$ in vitro transcription (IVT) reaction to generate aRNA (GeneChip 3/ IVT Express Kit; Affymetrix). Size distribution of the aRNA and fragmented aRNA, respectively, was assessed using an Agilent 2100 Bioanalyzer with a RNA 6000 Nano Assay.

$15 \mu \mathrm{g}$ of fragmented aRNA was used in a $300 \mu \mathrm{l}$ hybridization cocktail containing added hybridization controls. $200 \mu \mathrm{l}$ of mixture was hybridized on arrays for $16 \mathrm{~h}$ at $45^{\circ} \mathrm{C}$. Standard post hybridization wash and double-stain protocols (FS450_0004; GeneChip HWS kit, Affymetrix) were used on an Affymetrix GeneChip Fluidics Station 450. Arrays were scanned on an Affymetrix GeneChip scanner 30007 G.

\section{GeneChip data analysis}

Scanned arrays were analyzed first with Affymetrix Expression Console software to obtain Absent/Present calls and to assure that all quality parameters were in the recommended range. Subsequent analysis was carried out with DNA-Chip Analyzer (dChip) 2010 (http://www. dchip.org, Cheng Li Lab, Harvard). The 6 arrays were normalized to a baseline array with median CEL intensity by applying an Invariant Set Normalization Method [83].
Normalized CEL intensities of the arrays were used to obtain model-based gene expression indices based on a PM (Perfect Match)-only model [84]. Replicate data (triplicates) for the conditions were weighted gene-wise by using inverse squared standard error as weights. Genes compared were considered to be differentially expressed if the 90\% lower confidence bound of the fold change between experiment and baseline was above 1.3. The lower confidence bound criterion means that we can be $90 \%$ confident that the fold change is a value between the lower confidence bound and a variable upper confidence bound. $\mathrm{Li}$ and Wong $[83,84]$ have shown that the lower confidence bound (LBFC) is a conservative estimate of the fold change and therefore more reliable as a ranking statistic for changes in gene expression.

\section{Quantitative real-time PCR (qPCR)}

Samples from the same RNA preparations used in the microarray experiment were reverse transcribed using Promega Reverse Transcription System and poly $(\mathrm{dT})_{12-18}$ to prime the reactions. cDNA was amplified using the $\mathrm{iQ}^{\mathrm{TM}}$ $\mathrm{SYBR}^{\circledR}$ Green Supermix on the $\mathrm{iQ}^{\mathrm{TM}} 5$ Real-Time PCR Detection System (Biorad).

All qPCR reactions were run in duplicates. Thermocycle settings were as follows: Initial denaturation of $3 \mathrm{~min}$ at $95^{\circ} \mathrm{C}$, followed by forty cycles, each consisting of $10 \mathrm{~s}$ at

Table 5 Oligonucleotide primer sequences used in qPCR and in reverse-transcription PCR assays

\begin{tabular}{|c|c|c|c|}
\hline AGI ID & primer ID & Forward primer & Reverse primer \\
\hline At4g05320 & UBQ10 & gctccgacaccattgacaac & acgcaggaccaagtgaagag \\
\hline At1g71380 & ATCEL3 & tctccaagtcattgctcttcttcc & cgttgtctcctgcgtcatagtac \\
\hline At3g60570 & ATEXPB5 & gcaaacggtgatgggaacttcg & ggacacggcggaggtaagc \\
\hline At5g11110 & ATSPS2F & tggtggtgttcgtgggagattcag & ttagcctcggtgatgttgggactg \\
\hline At1g53540 & HSP17.6C-Cl & ggcaaacgcacccgctatg & ttcacctcttccttcctcagtcc \\
\hline AT2g46500 & AT2g46500 & agacggctcaaacgctcagaatc & cggatagggcttcgaggaatgc \\
\hline At2g39890 & PROT1 & atggcgagaggcgggtac & gtggttggctagaatgaatgtgag \\
\hline At1g50490 & UBC20 & agatcctccggcgtctaatgg & tgcttcctgttattgtccctttcc \\
\hline At5g60250 & AT5g60250 & cggttacagatggaggaggcactc & aggacaccacacgtagccacaatc \\
\hline At1g68610 & At1g68610 & ctctaacgaccaaccaagccaag & acatcgctccgctcacacc \\
\hline At4g27960 & UBC9 & gtttcaccaccctttcttc & aaatcccacgatcaaattcc \\
\hline At2g19970 & At2g19970 & gagacattctgatggaccttacg & tccgagacttaacgattgattgg \\
\hline At1g65760 & At1g65760 & cgatgattcctacattagcagac & aagacgcaacgggtaacg \\
\hline At2g22340 & At2g22340 & gcgacggtgggatttcaggaactg & gatgggagcggcaacggatgtg \\
\hline At5g28380 & At5g28380 & aagcacactgcgaccaaggc & cagcggctcatggatctcactac \\
\hline At4g09950 & At4g09950 & ggaggatgtgaaggagcaattagc & tcttgttgagttcggtgcgtaac \\
\hline At1g12840 & DET3 & cggcgttcttggcatgtgtc & agcaaggttgatagtgaaggagac \\
\hline At1g51490 & BGLU36 & gccgtactctctcgctgtcaaag & atgagccagaagttcgtgatgtcc \\
\hline At3g57880 & C2 domain-containing protein & caggatgaggtatrgacaggttgag & gcggcaatcaagcagaacaag \\
\hline At4g20780 & CML42 & cccaagcctaaacgcacttcg & acggtggatttgagatcggagag \\
\hline At2g19970 & CAP (Antigen 5) & gagacattctgatggaccttacg & tccgagacttaacgattgattgg \\
\hline At2g19980 & CAP (allergen V5) & gcacagaggtacgctaacg & ggtggcataattgtaataaggc \\
\hline
\end{tabular}


Table 6 Oligonucleotide primer sequences used in the DNA constructions for the $\mathrm{Y} 2 \mathrm{H}$ assays

\begin{tabular}{llll}
\hline AGI ID & primer ID & Forward primer & Reverse primer \\
\hline At5g14380 & AGP6 & ggggacaagtttgtacaaaaaagcaggctcggccgacgctccctcagcttctcc & ggggaccactttgtacaagaaagctgggtcctaactcttgggtgactctgcagtgg \\
\hline At3g01700 & AGP11 & ggggacaagtttgtacaaaaaagcaggctcggccgatgcaccttcagctgcacc & ggggaccactttgtacaagaaagctgggtcctaacttttgggtgactcggcggc \\
\hline At1g26630 & FBR12 & ggggacaagtttgtacaaaaaagcaggctcgaccttcctcttcccctcc & ggggaccactttgtacaagaaagctgggtcctagtgcaaatagcaatgaatatc \\
\hline At4g05320 & UBQ10 & ggggacaagtttgtacaaaaaagcaggctcgaaatcttaaaaactttctctc & ggggaccactttgtacaagaaagctgggtcctaaaacaaaagaagcacagataat \\
\hline At3g18040 & MAPK9 & ggggacaagtttgtacaaaaaagcaggctcggcgaaaagtttctcccttg & ggggaccactttgtacaagaaagctgggtcctatgaagaaaacacacactttaac \\
\hline At1g70810 & $\begin{array}{l}\text { CaLB } \\
\text { domain } \\
\text { family } \\
\text { protein }\end{array}$ & ggggacaagtttgtacaaaaaagcaggctcgaaaagagtcagagccgc & ggggaccactttgtacaagaaagctgggtcctaaaaccaaaacgatttagg \\
\hline At2g30020 & AP2C1 & ggggacaagtttgtacaaaaaagcaggctcgcgaaatcgaaatcaaaatatag & ggggaccactttgtacaagaaagctgggtcctaaatttcggccaatgctcg \\
\hline
\end{tabular}

$95^{\circ} \mathrm{C}, 30 \mathrm{~s}$ at $56^{\circ} \mathrm{C}$ and $30 \mathrm{~s}$ at $72^{\circ} \mathrm{C}$. After each run, a dissociation curve was acquired to check for amplification specificity by heating the samples from 60 to $95^{\circ} \mathrm{C}$.

Serial dilutions of both agp6 agp11 and wild type pollen tube cDNA were used to determine the efficiency curve of each primer pair. The primers used are listed in Table 5. UBQ10 was used as internal reference gene. At the end of the PCR cycles, the data was analyzed with the iQ5 2.0, Standard Edition Optical System Software v2.0.148.060623 (Biorad), using the Livak calculation method [85].

\section{Semi quantitative reverse transcription (RT)-PCR}

cDNA samples used in qPCR experiments were also used in the RT-PCR assays. RT-PCR reactions were done on 8 genes, and two reference genes, UBC9 and UBQ10 (Table 5). PCR reactions were set up with DreamTaq DNA Polymerase (Fermentas). Each PCR reaction was initiated with a $5 \mathrm{~min}$ denaturation at $95^{\circ} \mathrm{C}$ followed cycles of $30 \mathrm{~s}$ at $95^{\circ} \mathrm{C}, 30 \mathrm{~s}$ at $56^{\circ} \mathrm{C}$ (for all primer pairs) and $30 \mathrm{~s}$ at $72^{\circ} \mathrm{C}$. Samples were taken after 25, 30 and 35 cycles. cDNA quantities were normalized for each sample using the two reference genes. Band intensity was assessed using Kodak DC120 Gel Electrophoresis Analysis System.

\section{Yeast Two-hybrid library screening assays}

The predicted peptide cores of AGP6 and AGP11, followed by a stop codon, were individually cloned into the pGBTKT7 vector (Clontech, Palo Alto, CA), modified at the XmaI site to include a Gateway cassette. The bait constructs were introduced in the $\alpha-Y 187$ strain [86]. YPAD, SD, and appropriate dropout media have been described previously [87].

The bait strains were mated with a normalized Arabidopsis thaliana total plant cDNA library cloned in pGADrec (Sommer and Masiero, unpublished data) and introduced in the $\alpha$-AH109 yeast strain (Clontech).

Colonies that grew on all selective media (-Trp-LeuAdenine-His and supplemented with $15 \mathrm{mM}$ 3-Amino- 1,2,4-triazole) were further characterized. The pGADrec plasmids were rescued and cDNA insert was amplified by PCR and sequenced.

\section{Yeast Two-hybrid interaction assays}

cDNA of each candidate gene was used to perform confirmation of the interaction. RNA was extracted from Arabidopsis inflorescences containing flowers in several stages of development using the RNeasy Mini Kit (Qiagen). cDNA was synthesized with the RevertAid First Strand cDNA Synthesis Kit (Thermo Scientific, Waltham, MA, USA). Full-length cDNA of these genes was amplified by PCR (Table 6) with Phusion High-Fidelity DNA Polymerase (New England Biolabs, Ipswich, MA, USA) and purified from agarose gel using the GeneJET Gel Extraction Kit (Thermo Scientific). In case of alternative splicing forms, the splice selected was the one corresponding to the mature form according to TAIR. The cDNA sequence of each gene was individually cloned into the pGADT7 vector (Clontech).

Each bait/prey pair was introduced in the $\alpha$-AH109 yeast strain (Clontech), and as a control for autoactivation false-positives, each bait was also co-transformed into the yeast strain with the empty $\mathrm{AD}$ vector, and each prey was co-transformed with the empty BD vector. Bait/prey pair colonies that grew on all selective media (-Trp-Leu-Adenine-His and supplemented with increasing concentrations of $1 \mathrm{mM}$ to $2.5 \mathrm{mM} 3$-Amino-1,2,4triazole) were considered positive for interaction.

\section{Additional files}

\section{Additional file 1: agp6 agp11 mutant microarray data.}

Additional file 2: Differentially expressed genes common to agp6 agp11 mutant and treatment with Yariv phenylglycoside reagent for $1 \mathrm{~h}$ and $10 \mathrm{~h}$.

\section{Authors' contributions}

MC carried out the molecular genetic studies; MSN carried out the yeasttwo-hybrid assays; SM designed the yeast-two-hybrid assays; JB carried out the microarray experiment; MIA participated in the data analysis; LGP 
participated in the design of the study and helped to draft the manuscript. SC, PI of the project conceived the study and its coordination and drafted the manuscript. All authors read and approved the final manuscript.

\section{Acknowledgements}

The authors would like to thank Yu Guan and Eugene Nothnagel for kindly supplying their microarray files and to Zoë Popper for kindly reading the manuscript.

This work was supported by FEDER funds through the COMPETE program and by FCT (Fundação para a Ciência e Tecnologia, Portugal) national funds within the projects PTDC/AGR-GPL/67971/2006 and PTDC/AGR-GPL/115358/ 2009. Additionally, COST Action FA0903 supported the collaborative research visit made by MSN to the University of Milan.

\section{Author details}

'Departamento de Biologia, Faculdade de Ciências, Universidade do Porto, Edifício FC4 Rua do Campo Alegre, 4169-007, Porto, Portugal. ${ }^{2}$ BioFIG, Center for Biodiversity, Functional and Integrative Genomics, Porto, Portugal. ${ }^{3}$ Instituto Gulbenkian de Ciência, Oeiras 2780-901, Portugal. ${ }^{4}$ Dipartimento di Biologia, Università degli Studi di Milano, Milan 20133, Italy.

Received: 1 October 2012 Accepted: 28 December 2012 Published: 8 January 2013

\section{References}

1. Campanoni $P$, Blatt MR: Membrane trafficking and polar growth in root hairs and pollen tubes. J Exp Bot 2007, 58(1):65-74.

2. Becker JD, Boavida LC, Carneiro J, Haury M, Feijó JA: Transcriptional profiling of Arabidopsis tissues reveals the unique characteristics of the pollen transcriptome. Plant Physiol 2003, 133:713-725.

3. Honys D, Twell D: Comparative analysis of the Arabidopsis pollen transcriptome. Plant Physiol 2003, 132(2):640-652.

4. Pina C, Pinto F, Feijó JA, Becker JD: Gene family analysis of the Arabidopsis pollen transcriptome reveals biological implications for cell growth, division control, and gene expression regulation. Plant Physiol 2005, 138(2):744-756.

5. Wang $Y$, Zhang WZ, Song LF, Zou JJ, Su Z, Wu WH: Transcriptome analyses show changes in gene expression to accompany pollen germination and tube growth in Arabidopsis. Plant Physiol 2008, 148(3):1201-1211.

6. Qin Y, Leydon AR, Manziello A, Pandey R, Mount D, Denic S, Vasic B, Johnson MA, Palanivelu R: Penetration of the stigma and style elicits a novel transcriptome in pollen tubes, pointing to genes critical for growth in a pistil. PLoS Genet 2009, 5(8):e1000621.

7. Honys D, Twell D: Transcriptome analysis of haploid male gametophyte development in Arabidopsis. Genome Biol 2004, 5(11):R85.

8. Borner GHH, Sherrier DJ, Weimar T, Michaelson LV, Hawkins ND, MacAskill A, Napier JA, Beale MH, Lilley KS, Dupree P: Analysis of detergent-resistant membranes in Arabidopsis. Evidence for plasma membrane lipid rafts. Plant Physiol 2005, 137:104-116.

9. Yariv J, Lis H, Katchalski E: Precipitation of arabic acid and some seed polysaccharides by glycosylphenylazo dyes. Biochem J 1967, 105(1):1C-2C.

10. Ellis M, Egelund J, Schultz CJ, Bacic A: Arabinogalactan-proteins: key regulators at the cell surface? Plant Physiol 2010, 153:403-419.

11. Coimbra S, Costa M, Jones B, Mendes MA, Pereira LG: Pollen grain development is compromised in Arabidopsis agp6 agp11 null mutants. J Exp Bot 2009, 60(11):3133-3142.

12. Coimbra S, Costa M, Mendes MA, Pereira AM, Pinto J, Pereira LG: Early germination of Arabidopsis pollen in a double null mutant for the arabinogalactan protein genes AGP6 and AGP11. Sex Plant Reprod 2010, 23(3):199-205.

13. Provart N, Zhu T: A browser-based functional classification superviewer for arabidopsis genomics. Currents Comput Mol Biol 2003, :271-272.

14. Berardini TZ, Mundodi S, Reiser $L$, Huala E, Garcia-Hernandez M, Zhang $P$, Mueller LA, Yoon J, Doyle A, Lander G, Moseyko N, Yoo D, Xu I, Zoeckler B, Montoya M, Miller N, Weems D, Rhee SY: Functional annotation of the Arabidopsis genome using controlled vocabularies. Plant Physiol 2004, 135(2):745-755

15. Warde-Farley D, Donaldson SL, Comes O, Zuberi K, Badrawi R, Chao P, Franz M, Grouios C, Kazi F, Lopes CT, Maitland A, Mostafavi S, Montojo J, Shao Q, Wright G, Bader GD, Morris Q: The GeneMANIA prediction server: biological network integration for gene prioritization and predicting gene function. Nucleic Acids Res 2010, 38(Suppl 2):W214-W220.

16. Bindschedler LV, Palmblad M, Cramer R: Hydroponic isotope labelling of entire plants (HILEP) for quantitative plant proteomics; an oxidative stress case study. Phytochemistry 2008, 69(10):1962-1972.

17. Fernandez-Calvino L, Faulkner C, Walshaw J, Saalbach G, Bayer E, BenitezAlfonso Y, Maule A: Arabidopsis plasmodesmal proteome. PLoS One 2011, 6(4):e18880.

18. Ito J, Batth TS, Petzold CJ, Redding-Johanson AM, Mukhopadhyay A, Verboom R, Meyer EH, Millar AH, Heazlewood JL: Analysis of the arabidopsis cytosolic proteome highlights subcellular partitioning of central plant metabolism. J Proteome Res 2011, 10(4):1571-1582.

19. Mitra S, Gantt J, Ruby J, Clouse S, Goshe M: Membrane proteomic analysis of arabidopsis thaliana using alternative solubilization techniques. J Proteome Res 2007, 6(5):1933-1950.

20. Kronegg J, Buloz D: Detection/prediction of GPI cleavage site (GPl-anchor) in a protein (DGPI):; 1999. http://129.194.185.165/dgpi/.

21. Schwacke R, Fischer K, Ketelsen B, Krupinska K, Krause K: Comparative survey of plastid and mitochondrial targeting properties of transcription factors in Arabidopsis and rice. Mol Genet Genomics 2007, 277(6):631-646.

22. Schwacke R, Schneider A, van der Graaff E, Fischer K, Catoni E, Desimone M, Frommer WB, Flügge UI, Kunze R: ARAMEMNON, a novel database for arabidopsis integral membrane proteins. Plant Physiol 2003, 131(1):16-26.

23. Yilmaz A, Mejia-Guerra MK, Kurz K, Liang X, Welch L, Grotewold E: AGRIS: arabidopsis gene regulatory information server, an update. Nucleic Acids Res 2011, 39:D1118-D1122.

24. Zybailov B, Rutschow H, Friso G, Rudella A, Emanuelsson O, Sun Q, van Wijk $\mathrm{KJ}$ : Sorting signals, N-terminal modifications and abundance of the chloroplast proteome. PLoS One 2008, 3(4):e1994.

25. Book AJ, Gladman NP, Lee SS, Scalf M, Smith LM, Vierstra RD: Affinity purification of the Arabidopsis $26 \mathrm{~S}$ proteasome reveals a diverse array of plant proteolytic complexes. J Biol Chem 2010, 285(33):25554-25569.

26. Yang $H$, Yang S, Li Y, Hua J: The Arabidopsis BAP1 and BAP2 genes are general inhibitors of programmed cell death. Plant Physiol 2007, 145:135-146.

27. Benschop JJ, Mohammed S, O'Flaherty M, Heck AJ, Slijper M, Menke FL: Quantitative phosphoproteomics of early elicitor signalling in Arabidopsis. Mol Cell Proteomics 2007, 6(7):1198-1214.

28. Marmagne A, Ferro M, Meinnel T, Bruley C, Kuhn L, Garin J, Barbier-Brygoo $H$, Ephritikhine G: A high content in lipid-modified peripheral proteins and integral receptor kinases features the Arabidopsis plasma membrane proteome. Mol Cell Proteomics 2007, 6(11):1980-1996.

29. Bayer EM, Bottrill AR, Walshaw J, Vigouroux M, Naldrett MJ, Thomas CL, Maule AJ: Arabidopsis cell wall proteome defined using multidimensional protein identification technology. Proteomics 2006 6(1):301-311.

30. Jaquinod M, Villiers F, Kieffer-Jaquinod S, Hugouvieux V, Bruley C, Garin J, Bourguignon J: A proteomic dissection of Arabidopsis thaliana vacuoles isolated from cell culture. Mol Cell Proteomics 2007, 6(3):394-412.

31. Parsons HT, Christiansen K, Knierim B, Carroll A, Ito J, Batth TS, Smith-Moritz AM, Morrison S, Mclnerney P, Hadi MZ, Auer M, Mukhopadhyay A, Petzold CJ, Scheller HV, Loque D, Heazlewood JL: Isolation and proteomic characterization of the arabidopsis golgi defines functional and novel components involved in plant cell wall biosynthesis. Plant Physiol 2012, 159(1):12-26.

32. Nikolovski N, Rubtsov D, Segura MP, Miles GP, Stevens TJ, Dunkley TP, Munro S, Lilley KS, Dupree P: Putative glycosyltransferases and other plant Golgi apparatus proteins are revealed by LOPIT proteomics. Plant Physiol, in Press.

33. Borderies G, Jamet E, Lafitte C, Rossignol M, Jauneau A, Boudart G, Monsarrat B, Esquerré-Tugayé MT, Boudet A, Pont-Lezica R: Proteomics of loosely bound cell wall proteins of Arabidopsis thaliana cell suspension cultures: a critical analysis. Electrophoresis 2003, 24(19-20):3421-3432.

34. Lewis JD, Lazarowitz SG: Arabidopsis synaptotagmin SYTA regulates endocytosis and virus movement protein cell-to-cell transport. Proc Natl Acad Sci USA 2010, 107(6):2491-2496.

35. Yamazaki T, Kawamura Y, Minami A, Uemura M: Calcium-dependent freezing tolerance in Arabidopsis involves membrane resealing via synaptotagmin SYT1. Plant Cell 2008, 20(12):3389-3404.

36. Minic Z, Jamet E, Négroni L, Arsene der Garabedian P, Zivy M, Jouanin L: A sub-proteome of Arabidopsis thaliana mature stems trapped on 
Concanavalin A is enriched in cell wall glycoside hydrolases. J Exp Bot 2007, 58(10):2503-2512.

37. Oliviusson P, Heinzerling O, Hillmer S, Hinz G, Tse YC, Jiang L, Robinson DG: Plant retromer, localized to the prevacuolar compartment and microvesicles in Arabidopsis, may interact with vacuolar sorting receptors. Plant Cell 2006, 18:1239-1252.

38. Jaillais Y, Santambrogio M, Rozier F, Fobis-Loisy I, Miège C, Gaude T: The retromer protein VPS29 links cell polarity and organ initiation in plants. Cell 2007, 130:1057-1070.

39. Kleine-Vehn J, Leitner J, Zwiewka M, Sauer M, Abas L, Luschnig C, Friml J: Differential degradation of PIN2 auxin efflux carrier by retromerdependent vacuolar targeting. Proc Natl Acad Sci USA 2008, 105(46):17812-17817.

40. Grienenberger E, Besseau S, Geoffroy P, Debayle D, Heintz D, Lapierre C, Pollet B, Heitz T, Legrand M: A BAHD acyltransferase is expressed in the tapetum of Arabidopsis anthers and is involved in the synthesis of hydroxycinnamoyl spermidines. Plant J 2009, 58(2):246-259.

41. Dobritsa AA, Geanconteri A, Shrestha J, Carlson A, Kooyers N, Coerper D, Urbanczyk-Wochniak E, Bench BJ, Sumner LW, Swanson R, Preuss D: A large-scale genetic screen in Arabidopsis to identify genes involved in pollen exine production. Plant Physiol 2011, 157(2):947-970.

42. Brock AK, Willmann R, Kolb D, Grefen L, Lajunen HM, Bethke G, Lee J, Nürnberger T, Gust AA: The Arabidopsis mitogen-activated protein kinase phosphatase PP2C5 affects seed germination, stomatal aperture, and abscisic acid-inducible gene expression. Plant Physiol 2010, 153(3):1098-1111.

43. Schweighofer A, Kazanaviciute V, Scheikl E, Teige M, Doczi R, Hirt H, Schwanninger M, Kant M, Schuurink R, Mauch F, Buchala A, Cardinale F, Meskiene I: The PP2C-type phosphatase AP2C1, which negatively regulates MPK4 and MPK6, modulates innate immunity, jasmonic acid, and ethylene levels in Arabidopsis. Plant Cell 2007, 19(7):2213-2224.

44. Guan Y, Nothnagel EA: Binding of arabinogalactan proteins by Yariv phenylglycoside triggers wound-like responses in Arabidopsis cell cultures. Plant Physiol 2004, 135(3):1346-1366.

45. Ding L, Zhu J-K: A role for arabinogalactan-proteins in root epidermal cell expansion. Planta 1997, 203:289-294.

46. Roy S, Jauh GY, Hepler PK, Lord EM: Effects of Yariv phenylglycoside on cell wall assembly in the Lily pollen tube. Planta 1998, 204:450-458.

47. Molle J-C, Kim S, Jauh Y, Lord EM: Arabinogalactan proteins, pollen tube growth, and the reversible effect of Yariv phenylglycoside. Protoplasma 2002, 219:89-98.

48. Nguema-Ona E, Banningan A, Chevalier L, Baskin Tl, Driouich A: Disruption of arabinogalactan proteins disorganizes cortical microtubules in the root of Arabidopsis thaliana. Plant J 2007, 52:240-251.

49. Kipreos ET, Pagano M: The F-box protein family. Genome Biol 2000, 1(5):R3002.

50. Xu G, Ma H, Nei M, Kong H: Evolution of F-box genes in plants:different modes of sequence divergence and their relationships with functional diversification. Proc Natl Acad Sci USA 2009, 106:835-840.

51. Skaar JR, Pagan JK, Pagano M: SnapShot: F-box proteins I. Cell 2009, 137:1160-1161.

52. Hua Z, Zou C, Shiu S-H, Vierstra RD: Phylogenetic comparison of F-Box (FBX) superfamily within the plant kingdom reveals divergent evolutionary histories indicative of genomic drift. PLOS One 2011, 6:e16219.

53. Gusti A, Baumberger N, Nowack M, Pusch S, Eisler H, Potuschak T, De Veylder L, Schnittger A, Genschik P: The Arabidopsis thaliana F-Box protein FBL17 is essential for progression through the second mitosis during pollen development. PLoS One 2009, 4(3):e4780.

54. Doelling JH, Phillips AR, Soyler-Ogretim G, Wise J, Chandler J, Callis J, Otegui MS, Vierstra RD: The ubiquitin-specific protease subfamily UBP3/UBP4 is essential for pollen development and transmission in Arabidopsis. Plant Physiol 2007, 145:801-813.

55. Dobney S, Chiasson D, Lam P, Smith SP, Snedden WA: The calmodulinrelated calcium sensor CML42 plays a role in trichome branching. J Biol Chem 2009, 284(46):31647-31657.

56. Popescu SC, Popescu GV, Bachan S, Hang Z, Seay M, Gerstein M, Snyder M, Dinesh-Kumar SP: Differential binding of calmodulin-related proteins to their targets revealed through high-density Arabidopsis protein microarrays. Proc Natl Acad Sci USA 2007, 104(11):4730-4735.
57. Schiøtt M, Romanowsky SM, Bækgaard L, Jakobsen MK, Palmgren MG, Harper J: A plant plasma membrane $\mathrm{Ca}^{2+}$ pump is required for normal pollen tube growth. Proc Natl Acad Sci USA 2004, 101:9502-9507.

58. Allen AM, Lexer C, Hiscock SJ: Comparative analysis of pistil transcriptomes reveals conserved and novel genes expressed in dry, wet and semidry stigmas. Plant Physiol 2010, 154:1347-1360.

59. Boavida LC, Borges F, Becker JD, Feijó JA: Whole genome analysis of gene expression reveals coordinated activation of signaling and metabolic pathways during pollen-pistil interactions in Arabidopsis. Plant Physiol 2011, 155:2066-2080.

60. Elleman CJ, Dickinson HG: Commonalities between pollen/stigma and host/pathogen interactions: Calcium accumulation during stigmatic penetration by Brassica oleracea pollen tubes. Sex Plant Reprod 1999, 12:194-202.

61. Gibbs GM, Roelants K, O'Bryan MK: The CAP superfamily: Cysteine-rich secretory proteins, Antigen 5, and Pathogenesis-related 1 proteins roles in reproduction, cancer, and immune defense. Endocr Rev 2008, 29:865-897.

62. Gibbs GM, Lo JCY, Nixon B, Jamsai D, O'Connor AE, Rijal S, Sanchez-Partida LG, Hearn MTW, Bianco DM, O'Bryan MK: Glioma pathogenesis-related 1like 1 is testis enriched, dynamically modified, and redistributed during male germ cell maturation and has a potential role in sperm-oocyte binding. Endocrinology 2010, 151:2331-2342.

63. Ohnishi T, Takanashi H, Mogi M, Takahashi H, Kikuchi S, Yano K, Okamoto T, Fujita M, Kurata N, Tsutsumi N: Distinct gene expression profiles in egg and synergid cells of rice as revealed by cell type-specific microarrays. Plant Physiol 2011, 155:881-891.

64. Kessler SA, Shimosato-Asano H, Keinath NF, Wuest SE, Ingram G, Panstruga R, Grossniklaus U: Conserved Molecular Components for Pollen Tube Reception and Fungal Invasion. Science 2010, 330(6006):968-971.

65. Govers F, Angenent GC: Fertility goddesses as trojan horses. Science 2010, 330(6006):922-923.

66. Rotin D, Staub O, Haguenauer-Tsapis R: Ubiquitination and endocytosis of plasma membrane proteins:role of Nedd4/Rsp5p family of ubiquitinprotein ligases. J Membr Biol 2000, 176:1-17.

67. Dunn R, Klos DA, Adler AS, Hicke L: The C2 domain of the Rsp5 ubiquitin ligase binds membrane phosphoinositides and directs ubiquitination of endosomal cargo. J Cell Biol 2004, 165(1):135-144.

68. Šamaj J, Read ND, Volkmann D, Menzel D, Baluska F: The endocytic network in plants. Trends Cell Biol 2005, 15:425-433.

69. Robinson DG, Jiang L, Schumacher K: The endosomal system of plants: Charting new and familiar territories. Plant Physiol 2008, 147:1482-1492.

70. Zhao Y, Yan A, Feijó JA, Furutani M, Takenawa T, Hwang I, Fu Y, Yang Z: Phosphoinositides regulate clathrin-dependent endocytosis at the tip of pollen tubes in Arabidopsis and tobacco. Plant Cell 2010, 22(12):4031-4044.

71. Herman EM, Lamb CJ: Arabinogalactan-rich glycoproteins are localized on the cell surface and in intravacuolar multivesicular bodies. Plant Physiol 1992, 98:264-272.

72. Šamaj J, Šamajová O, Peters M, Baluška F, Lichtscheidl I, Knox JP, Volkmann D: Immunolocalization of LM2 arabinogalactan-protein epitope associated with endomembranes of plant cells. Protoplasma 2000, 212:186-196.

73. Dettmer J, Hong-Hermesdorf A, Stierhof YD, Schumacher K: Vacuolar H ${ }^{+}$-ATPase activity is required for endocytic and secretory trafficking in Arabidopsis. Plant Cell 2006, 18:715-730.

74. Schumacher K, Vafeados D, McCarthy M, Sze H, Wilkins T, Chory J: The Arabidopsis det3 mutant reveals a central role for the vacuolar $\mathrm{H}$ (+)-ATPase in plant growth and development. Genes Dev 1999, 13:3259-3270.

75. Catz SD, Johnson JL, Babior BM: The C2A domain of JFC1 binds to 3'-phosphorylated phosphoinositides and directs plasma membrane association in living cells. Proc Natl Acad Sci USA 2002, 99(18):11652-11657.

76. Yang $H, L i Y$, Hua J: The $C 2$ domain protein BAP1 negatively regulates defense responses in Arabidopsis. Plant J 2006, 48:238-248.

77. Lee CB, Swatek KN, McClure B: Pollen proteins bind to the C-terminal domain of Nicotiana alata pistil arabinogalactan proteins. J Biol Chem 2008, 283:26965-26973.

78. Pourcher M, Santambrogio M, Thazar N, Thierry AM, Fobis-Loisy I, Miège C, Jaillais $Y$, Gaude T: Analyses of sorting nexins reveal distinct retromer- 
subcomplex functions in development and protein sorting in Arabidopsis thaliana. Plant Cell 2010, 22(12):3980-3991.

79. Bove J, Vaillancourt B, Kroeger J, Hepler PK, Wiseman PW, Geitmann A: Magnitude and direction of vesicle dynamics in growing pollen tubes using spatiotemporal image correlation spectroscopy (STICS) and fluorescence recovery after photobleaching (FRAP). Plant Physiol 2008, 147(4):1646-1658.

80. Bosch M, Hepler PK: Pectin methylesterases and pectin dynamics in pollen tubes. Plant Cell 2005, 17(12):3219-3226.

81. Kuromori T, Hirayama T, Kiyosue Y, Takabe H, Mizukado S, Sakurai T, Akiyama K, Kamiya A, Ito T, Shinozaki K: A collection of 11800 single-copy Ds transposon insertion lines in Arabidopsis. Plant J 2004, 37:897-905.

82. Dardelle F, Lehner A, Ramdani Y, Bardor M, Lerouge P, Driouich A, Mollet JC: Biochemical and immunocytological characterizations of Arabidopsis pollen tube cell wall. Plant Physiol 2010, 153(4):1563-1576.

83. Li C, Wong HW: Model-based analysis of oligonucleotide arrays: expression index computation and outlier detection. Proc Natl Acad SCi USA 2001, 98:31-36.

84. Li C, Wong HW: Model-based analysis of oligonucleotide arrays: model validation, design issues and standard error application. Genome Biol 2001, 2(8):R32.

85. Livak KJ, Schmittgen TD: Analysis of relative gene expression data using real-time quantitative PCR and the 2(-Delta Delta $C(T))$ method. Methods 2001, 25(4):402-408.

86. Gietz D, St. Jean A, Woods RA, Schiestl RH: Improved method for high efficiency transformation of intact yeast cells. Nucleic Acids Res 1992, 20:1425.

87. Sherman F: Getting started with yeast. Methods Enzymol 2002, 350:3-41.

doi:10.1186/1471-2229-13-7

Cite this article as: Costa et al:: Expression-based and co-localization detection of arabinogalactan protein 6 and arabinogalactan protein 11 interactors in Arabidopsis pollen and pollen tubes. BMC Plant Biology 2013 13:7.

\section{Submit your next manuscript to BioMed Central and take full advantage of:}

- Convenient online submission

- Thorough peer review

- No space constraints or color figure charges

- Immediate publication on acceptance

- Inclusion in PubMed, CAS, Scopus and Google Scholar

- Research which is freely available for redistribution 